\title{
Study of the Corrosion Characteristics of Tunnel Fissures in a Karst Area in Southwest China
}

\author{
Yanjie Zhao, ${ }^{1}$ Fugang Wang $\mathbb{D}^{1},{ }^{1}$ Cangsong Li, ${ }^{2}$ Yuqing Cao, ${ }^{1}$ and Hailong Tian ${ }^{1}$ \\ ${ }^{1}$ Key Laboratory of Groundwater Resources and Environment Ministry of Education, Jilin University, Changchun 130021, China \\ ${ }^{2}$ China Railway Southwest Research Institute Co. Ltd., Chengdu, Sichuan 611731, China \\ Correspondence should be addressed to Fugang Wang; wangfugang@jlu.edu.cn
}

Received 24 February 2018; Revised 23 May 2018; Accepted 24 June 2018; Published 24 July 2018

Academic Editor: Luigi Borrelli

Copyright (C) 2018 Yanjie Zhao et al. This is an open access article distributed under the Creative Commons Attribution License, which permits unrestricted use, distribution, and reproduction in any medium, provided the original work is properly cited.

\begin{abstract}
The development of the fissures in soluble rock of karst areas directly affects the construction and operation safety of tunnel engineering. It is thus of theoretical and practical significance to study the characteristics of its corrosion and its influencing factors. Taking the Wulong tunnel as the research object, the numerical model of the study area was established to quantitatively analyze the corrosion range, corrosion ratio, and changes in the permeability and porosity of the fissures in soluble rock of karst areas of the tunnel over the past 100 years, and the simulation results were verified by field experiments. The results show that the main controlling factor of the fissure corrosion of the tunnel in the karst area is the flow rate. The corrosion range and corrosion ratio of the fissures of the tunnels in the karst area increased with temperature because the reaction rate constant increased with temperature, causing the reactions' equilibrium to move towards the direction of the solution. The larger the initial permeability and the larger the porosity of the fissures, the faster the fissures corrode. In the same time period, the fissures with high permeability and large porosity will lead to the permeability and porosity being more enhanced, thus causing the corrosion of the fissures to exhibit secondary enhancement effects. The opening of the dead-end pores greatly enhanced the permeability and slightly increased the porosity, which caused the differential corrosion of fissures in the karst area. The protection of the tunnel should be strengthened, mainly in strong hydrodynamic conditions and in the fracture development zone.
\end{abstract}

\section{Introduction}

Carbonate rocks account for $35 \%$ of the land area distribution of China $[1,2]$. The karst development is very strong in Southwest China, which often led to geohazards and a variety of accidents of engineering construction [3-8]. Due to the distribution of abundant mountains in Southwest China, the ratio of bridges and tunnels relative to roads or railways is mostly over $70 \%$, some up to $90 \%[2,9,10]$. The karst caves and subterranean rivers that are broadly distributed in karst regions often lead to accidents during tunnel construction and increase the cost of the tunnels' operation and maintenance [9-11]. The Wulong tunnel is one of the representative tunnel projects in the karst area of Southwest China. According to a preliminary investigation, karst doline, karst caves, and subterranean rivers were found in the tunnel crossing area $[2,9,10]$.
Elucidating the corrosion mechanism of carbonate rocks helps us analyze the corrosion development of the fissures in soluble rock of karst areas. Scholars have carried out many studies on the influence factors of karst development through experiments, numerical simulations, and other methods [12-24]. These studies showed that the corrosion of carbonate rocks was influenced by internal factors, such as geological structures and rock compositions, as well as external factors, such as flow rates (rainfall), temperature, and $\mathrm{pH}$.

In terms of the impact of fissures on karst corrosion, scholars have found that faults and fractures play a vital role in karst corrosion [25-27]. They found that in the unidirectional one-dimensional limestone fissures, the corrosion rate of the limestone fissures shows a nonlinear increase with time [16, 28-33]. At the same time, scholars have also studied the characteristics of fissures and pore evolution under two-dimensional [14] and three-dimensional conditions 
[17, 34-37]. In addition, by studying the changes in the microstructures of the carbonate rocks that were corroded, it was determined that corrosion is first determined by the lithology and its own structure [38-40].

As for the influence of external environmental factors, such as flow rates, on karst corrosion, which are based on the basic principles of mineral dissolution, scholars obtained the basic differential equation of calcite dissolution rates through experimental research and mathematical statistics $[15,41]$; based on the corrosion law and surface corrosion theory of carbonate rocks, it was concluded that the flow rate, surface area, and concentration of major ions obviously affect the dissolution $[22,23,42-44]$. To assess the temperature factor, carbonate rock corrosion experiments between $0^{\circ} \mathrm{C}$ and $250^{\circ} \mathrm{C}$ were conducted, using rate equations for the corresponding temperature conditions to discuss the influence of temperature on the dissolution, precipitation, and surface corrosion of carbonate minerals [13, 19, 21, 23, 45-51]. In terms of $\mathrm{pH}$, under natural conditions, the $\mathrm{pH}$ change in rain water is mostly caused by changes in the $\mathrm{CO}_{2}$ content of air $[22,23,28,52]$. Scholars found that the variation of $\mathrm{pCO}_{2}$ in the range of 1 50 atm obviously affected the corrosion of carbonate minerals $[22,23]$, while at $\mathrm{pCO}_{2}$ values of lower than 0.1 atm, $\mathrm{pCO}_{2}$ had very little influence on the corrosion of carbonate minerals [28, 52, 53].

For tunnel engineering in a karst area, the geological and hydrogeological natural conditions must be taken into consideration [54]. The systematic study of the corrosion mechanism by numerical simulation and field experiments is of great importance for tunnel operation and maintenance.

In this paper, the Wulong tunnel, a typical tunnel project in Southwest China, was studied. The corrosion range, corrosion ratio, and changes in the porosity and permeability of karst cracks in the tunnel vault within a timeframe of 100 years were analyzed, and the differences in corrosion were discussed.

\section{The Background of the Wulong Tunnel Engineering Area}

The Wulong tunnel is located in Wulong County of China (Figure 1) with a full length of $9418 \mathrm{~m}$; it stretches along with the Wujiang Canyon and goes through the Wuling Mountains, with a maximum burial depth of approximately $830 \mathrm{~m}$. The middle part of the tunnel passes through $3800 \mathrm{~m}$ of soluble rock. Many karst caves and subterranean rivers have been found in the Wulong tunnel engineering area. Therefore, the engineering geological and hydrogeological conditions in the tunnel area are very complicated.

Wulong County is subtropical, with four distinct seasons, rain and heat over the same period, temperatures between $-3.5^{\circ} \mathrm{C}$ and $41.7^{\circ} \mathrm{C}$, and annual precipitation of approximately 1000-1200 $\mathrm{mm}$.

Carbonate rocks and clastic rocks are predominant in the Wulong tunnel area. For the lithology of the tunnel from entrance to exit, see Table 1 and Figure 2.

The study site is located within the Maokou limestone formation $\left(\mathrm{P}_{1 \mathrm{~m}}\right)$, and it is close to the Wujiaping Formation $\left(\mathrm{P}_{2 \mathrm{w}}\right)$, which is a set of coal-bearing strata near the contact zone of insoluble and soluble rock. A large "Tiankeng," a karst doline (Yangaotuo doline), can be found on the ground above the tunnel (Figures 3 and 4(a)). The karst phenomenon is very developed near the area of the tunnel, and karst caves can be found in nearby strata (Figure 4(b)).

In the study area, groundwater mainly receives rainfall infiltration, and the recharge, runoff, and discharge are controlled by topography, lithology, and faults. Karst groundwater flows to the Wujiang River in the form of subterranean rivers and springs in the tunnel area. The $2^{\#}$ and $3^{\#}$ subterranean rivers pass through the middle section of the tunnel area, which is the most karst-developed section of the whole tunnel, having karst caves and karst funnels (Figures 2-4). The $2^{\#}$ river is located $4496 \mathrm{~m}$ from the tunnel entrance (Figure 2). The $3^{\#}$ river is located $4643 \mathrm{~m}$ from the tunnel entrance. The two subterranean rivers are both nearly orthogonal with the tunnel line. The $2^{\#}$ and $3^{\#}$ subterranean rivers inrushed into the tunnel many times during the tunnel construction, which caused great difficulties in the tunnel engineering construction and maintenance [55].

Karst fractures increase the contact area of water and carbonate rock, which is helpful to promote the corrosion of carbonate rock, and have a certain effect on the stability of tunnel bedrock. Moreover, the tunnel vault is one of the most vulnerable parts of a tunnel, and it is prone to cause tunnel accidents. Therefore, in this study, the most vulnerable area, the tunnel vault fracture zone, which is located under the Yangaotuo karst funnel and above the $2^{\#}$ and $3^{\#}$ subterranean rivers, was chosen as the key study area (Figures 2 and 3).

\section{The Fissure Evolution Model and Simulation Scheme in the Karst Area of the Tunnel}

3.1. Conceptual Model of the Fissures in the Karst Area of the Tunnel. According to field investigations, the geological/ hydrogeological conditions, length, hydrochemical characteristics, and flow rates of $2^{\#}$ and $3^{\#}$ subterranean rivers were similar. A conceptual model was established for the study area, the main fissure, and the damage zone, which is above the $2^{\#}$ subterranean river (Figure 5 ). Based on previous investigations about the impact zones of different sizes of faults and fissures [56-61], the widths of the impact zones are generally 5-10 meters. In this study, the length and width of the impact zone of the tunnel fracture zone are all set to 24 meters, and the height of the simulated area was set as 60 meters based on the saturated zone above the vault of the tunnel. In field conditions, groundwater infiltrates from the top fracture zone, flowing through fissures and finally converging into the subterranean rivers. In the model, the upper and lower boundaries of the model were set as constant flow boundaries, and the lateral boundaries were set as no flow boundaries (Figure 5). In the horizontal direction, the length of the long fissures is approximately $80 \mathrm{~m}$ and the length of the short fissure is approximately $5 \mathrm{~m}$ (Figure 5 ).

3.2. Numerical Model. The numerical model was constructed based on the conceptual model. The modeling area was divided into 10 layers in the vertical direction, with each layer 


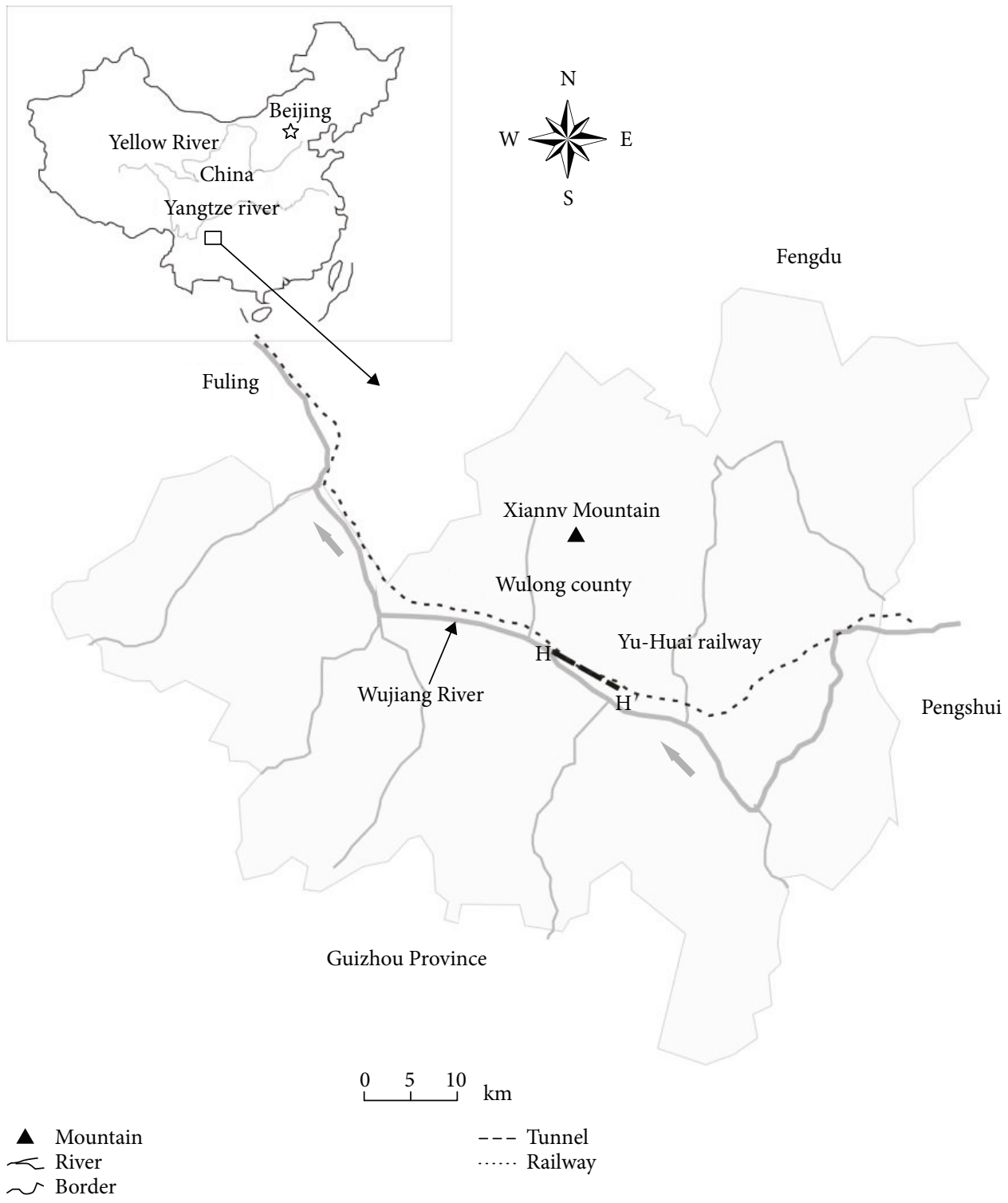

Figure 1: The location of the study area and tunnel project.

TABLe 1: Formation lithology of the Wulong tunnel area.

\begin{tabular}{|c|c|c|c|}
\hline System & \multicolumn{2}{|c|}{ Formation } & Lithology \\
\hline Jurassic & Zhenzhuchong & $\mathrm{J}_{1 \mathrm{z}}$ & Dark-brown shale and mudstone, light-gray sandstone \\
\hline \multirow{4}{*}{ Triassic } & Xujiahe & $\mathrm{T}_{3 \mathrm{xj}}$ & Dark-brown shale, light-gray sandstone \\
\hline & Leikoupo & $\mathrm{T}_{21}$ & $\begin{array}{c}\text { The upper part is dark-brown shale and marlstone. } \\
\text { The middle part is dark-brown shale and light-gray sandstone. } \\
\text { The lower part is gray limestone }\end{array}$ \\
\hline & Jialingjiang & $\mathrm{T}_{1 \mathrm{j}}$ & Gray limestone intercalated with dolomitic limestone \\
\hline & Feixianguan & $\mathrm{T}_{1 \mathrm{f}}$ & Gray limestone, dark-brown shale \\
\hline \multirow{4}{*}{ Permian } & Changxing & $\mathrm{P}_{2 \mathrm{c}}$ & Dark-gray limestone \\
\hline & Wujiaping & $\mathrm{P}_{2 \mathrm{w}}$ & Dark-gray limestone \\
\hline & Maokou & $\mathrm{P}_{1 \mathrm{~m}}$ & Gray and dark-gray limestone \\
\hline & Liangshan & $\mathrm{P}_{1 \mathrm{q}+1}$ & Limestone intercalated with bioclastic limestone \\
\hline Silurian & Luoreping & $\mathrm{S}_{11 \mathrm{r}}$ & Gray and dark-gray mudstone \\
\hline
\end{tabular}




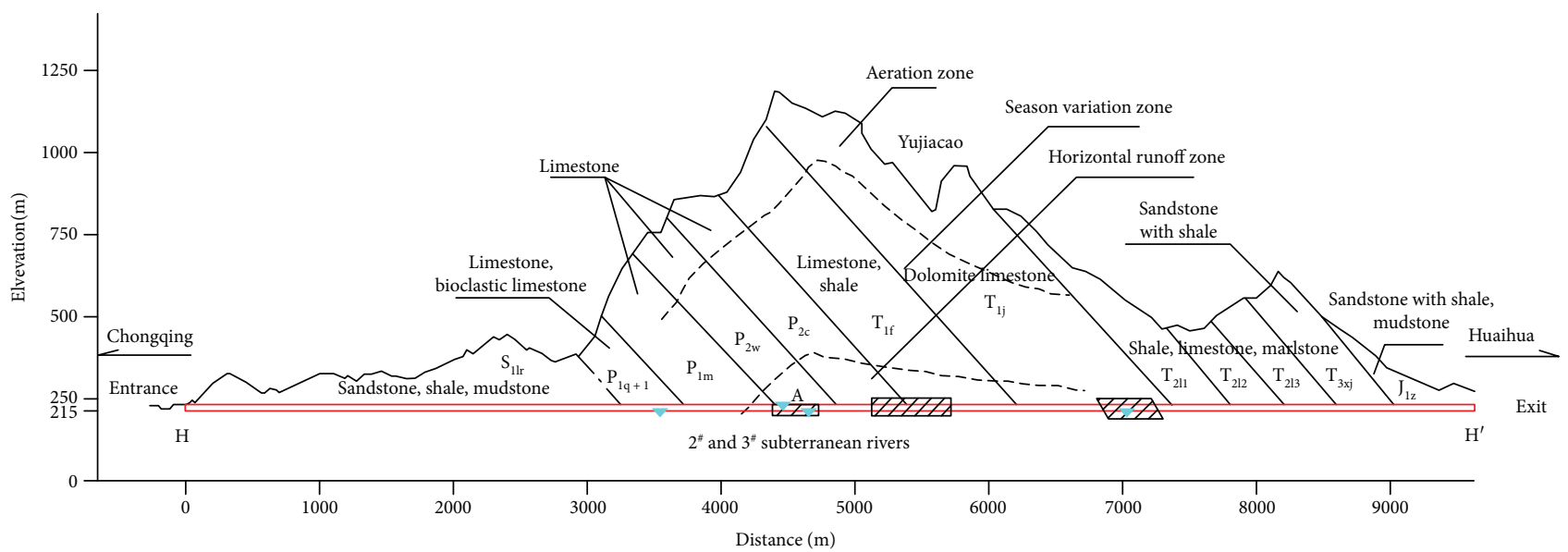

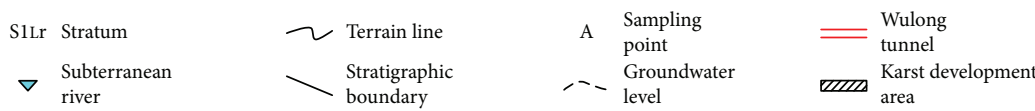

FIgURE 2: Simplified hydrogeological cross section of the Wulong tunnel area.
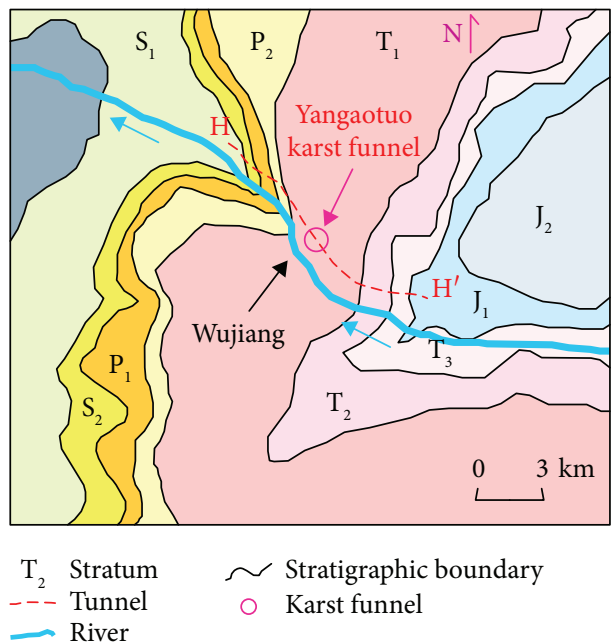

FIgURE 3: Geological map of the Wulong tunnel area.

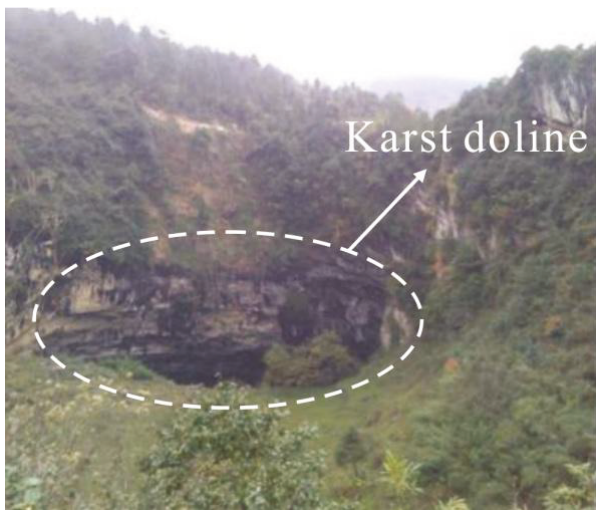

(a)

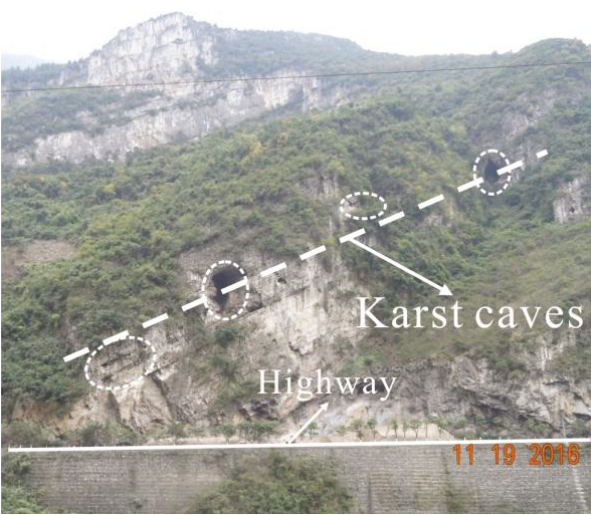

(b)

Figure 4: Karst phenomena in the study area ((a) karst doline; (b) karst caves). 


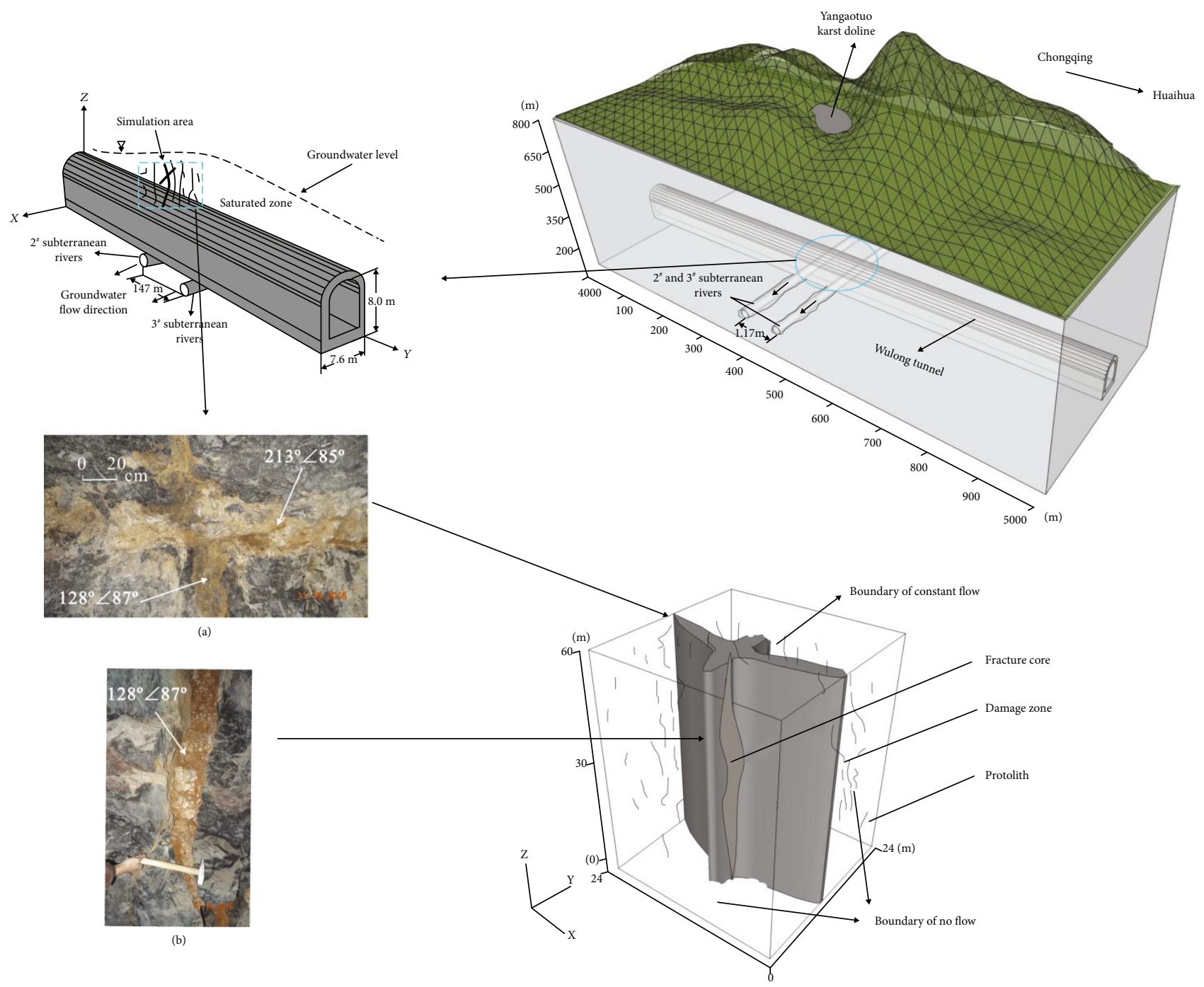

Figure 5: Conceptual model of the study area.

being 6 meters high, and the horizontal direction was divided into 6 columns, with each column being 4 meters wide; overall, the numerical model area was divided into 360 grids (Figure 6). The central part of the model is the fracture core zone; moving outward from this zone are the damage zone and protolith zone successively. In addition, the permeability and porosity decrease from the central part of the fracture zone to both sides outward (Figure 6).

3.3. Model Parameters and Simulation Scheme. According to previous research data $[9,10]$, the permeability of the karst fracture zone in the simulation area is between $1.8 \times 10^{-11} \mathrm{~m}^{2}$ and $1.3 \times 10^{-10} \mathrm{~m}^{2}$. The average permeability of $7.4 \times 10^{-11} \mathrm{~m}^{2}$ was taken as the permeability of the fracture core zone. To study the impacts of porosity and permeability on corrosion, a high-permeability condition of $7.4 \times 10^{-10} \mathrm{~m}^{2}$ and a low-permeability condition of $7.4 \times 10^{-12} \mathrm{~m}^{2}$ were additionally assigned to the fracture core zone in our study based on its range of empirical values. The permeability of the protolith is approximately $1 \times 10^{-17} \mathrm{~m}^{2} \sim 2.8 \times 10^{-13} \mathrm{~m}^{2}$ according to the measured data of the porosity and

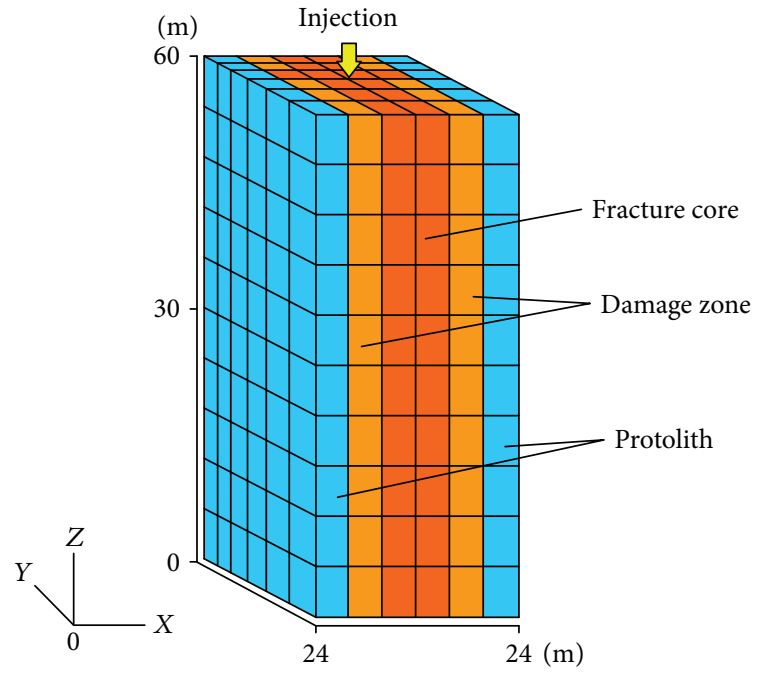

Figure 6: Numerical model. 
TABLE 2: Model parameters.

\begin{tabular}{lcccr}
\hline Category & Density $\left(\mathrm{kg} / \mathrm{m}^{3}\right)$ & Porosity & Water pressure $(\mathrm{Pa})$ & Permeability $\left(\mathrm{m}^{2}\right)$ \\
\hline Protolith & 2680 & $7 \%$ & $1 \times 10^{5} \sim 6 \times 10^{5}$ & $1.5 \times 10^{-14}$ \\
Fracture core & $2000 \sim 2280$ & $20 \% \sim 35 \%$ & & $7.9 \sim 790 \times 10^{-12}$ \\
\hline
\end{tabular}

TABLE 3: Karst ratio of the Wulong tunnel.

\begin{tabular}{lcc}
\hline $\begin{array}{l}\text { The starting position of each section } \\
\text { from the tunnel inlet }(\mathrm{m})\end{array}$ & $\begin{array}{c}\text { The length of the } \\
\text { section }(\mathrm{m})\end{array}$ & $\begin{array}{c}\text { Karst } \\
\text { ratio }\end{array}$ \\
\hline 0 3396 & 3396 & 0.2 \\
$3396 \sim 3892$ & 496 & 0.4 \\
$3892 \sim 5276$ & 1384 & 0.5 \\
$5276 \sim 7276$ & 2000 & 0.3 \\
$7276 \sim 9418$ & 2142 & 0.2 \\
\hline
\end{tabular}

permeability of the carbonatite (protolith) [62-64]. Therefore, in our model, the permeability of the protolith was set as $1.5 \times 10^{-14} \mathrm{~m}^{2}$. Because the damage zone is distributed around the fracture core zone, the permeability in the model gradually decreases from the fracture core zone outward to the protolith zone.

According to the tunnel investigation department and at the same time the reference of the empirical value in Southwest China, the porosity of the protolith is approximately $7 \%$ and the porosity of the fracture core zone is approximately $20 \%$ to $35 \%$. In the model, the porosity of the fracture core zone was set as $35 \%, 29 \%$, and $20 \%$, and the corresponding permeability values were set as $7.4 \times 10^{-10} \mathrm{~m}^{2}, 7.4 \times 10^{-11} \mathrm{~m}^{2}$, and $7.4 \times 10^{-12} \mathrm{~m}^{2}$, respectively. The porosity and permeability of the protolith were set as $7 \%$ and $1.5 \times 10^{-14} \mathrm{~m}^{2}$, respectively. The mineral composition and density of the protolith were determined by the measured data of calcite (95\%), illite (2\%), and montmorillonite (3\%). The chemical composition of groundwater was determined by water sample analysis, and its $\mathrm{pH}$ is 7.3. The water pressure range of the simulation area was assigned according to the field conditions (Table 1). The atmosphere temperature in the study area is between $-3.5^{\circ} \mathrm{C}$ and $\sim 41.7^{\circ} \mathrm{C}$, and the temperature of the groundwater is between $10^{\circ} \mathrm{C}$ and $25^{\circ} \mathrm{C}$. The temperatures of the injection water were set as $10^{\circ} \mathrm{C}, 15^{\circ} \mathrm{C}, 20^{\circ} \mathrm{C}, 25^{\circ} \mathrm{C}, 30^{\circ} \mathrm{C}$, and $35^{\circ} \mathrm{C}$ in our model. The model parameters are shown in Table 2. The karst ratios of different tunnel sections (Table 3) were obtained from analyzing the number of the fissures in soluble rock of karst areas and the karstification level $[9,10]$.

The simulation area is in the middle section of the tunnel (3892 m 5276 m), where the karst development is the strongest. Because the karst development depends on water-rock action, the flow rates directly influence the development of karst. According to the field investigation of the tunnel, based on the water balance principle $[9,10,65]$, the annual rainfall infiltration amount of the whole tunnel area was calculated. The water quantity of the whole tunnel area was then allocated to the different sections of the tunnel using the karst
TABLE 4: Simulation scenarios.

\begin{tabular}{|c|c|c|c|c|c|c|}
\hline \multirow[t]{2}{*}{$\begin{array}{l}\text { Scenario } \\
\text { code }\end{array}$} & \multirow{2}{*}{$\begin{array}{l}\text { Permeability } \\
\left(\mathrm{m}^{2}\right)\end{array}$} & \multirow[t]{2}{*}{ Porosity } & \multirow{2}{*}{$\begin{array}{c}\text { Temperature } \\
\left({ }^{\circ} \mathrm{C}\right)\end{array}$} & \multicolumn{3}{|c|}{$\begin{array}{c}\text { Flow rates } \\
(\mathrm{kg} / \mathrm{s})\end{array}$} \\
\hline & & & & $\mathrm{a}$ & $\mathrm{b}$ & c \\
\hline Case 1 & \multirow{6}{*}{$7.4 \times 10^{-10}$} & \multirow{6}{*}{$35 \%$} & 10 & \multirow{6}{*}{1.9} & \multirow{6}{*}{2.9} & \multirow{6}{*}{3.9} \\
\hline Case 2 & & & 15 & & & \\
\hline Case 3 & & & 20 & & & \\
\hline Case 4 & & & 25 & & & \\
\hline Case 5 & & & 30 & & & \\
\hline Case 6 & & & 35 & & & \\
\hline Case 7 & \multirow{6}{*}{$7.4 \times 10^{-11}$} & \multirow{6}{*}{$29 \%$} & 10 & \multirow{6}{*}{1.9} & \multirow{6}{*}{2.9} & \multirow{6}{*}{3.9} \\
\hline Case 8 & & & 15 & & & \\
\hline Case 9 & & & 20 & & & \\
\hline Case 10 & & & 25 & & & \\
\hline Case 11 & & & 30 & & & \\
\hline Case 12 & & & 35 & & & \\
\hline Case 13 & \multirow{6}{*}{$7.4 \times 10^{-12}$} & \multirow{6}{*}{$20 \%$} & 10 & \multirow{6}{*}{1.9} & \multirow{6}{*}{2.9} & \\
\hline Case 14 & & & 15 & & & \\
\hline Case 15 & & & 20 & & & \\
\hline Case 16 & & & 25 & & & 3.9 \\
\hline Case 17 & & & 30 & & & \\
\hline Case 18 & & & 35 & & & \\
\hline
\end{tabular}

ratios in Table 3; thus, the runoff distribution coefficient $k_{i}$ was obtained. $k_{i}$ can be calculated by

$$
k_{i}=\frac{r_{i} \times l_{i}}{\sum_{i=1}^{n} r_{i} \times l_{i}},
$$

where $r_{i}$ is the karst ratio and $l_{i}$ is the length of the tunnel section.

From the data in Table 3, the flow rates of different tunnel sections were calculated by (2). The flow rate of the simulated area in the model $\left(Q_{z}\right)$ was finally obtained by (3):

$$
\begin{gathered}
Q_{i}=k_{i} \times Q, \\
Q_{z}=k_{z} \times Q_{i},
\end{gathered}
$$

where $Q$ is the precipitation infiltration in the whole tunnel area and $k_{z}$ is the ratio of the simulation area size to the length of the most karst-developed parts of the tunnel.

According to the field conditions, the simulation time length was set as 100 years in consideration of the service period of the tunnel. The injection flow rates were based on the rainfall of the dry year, the normal flow year, and the wet year, that is, $800 \mathrm{~mm}, 1100 \mathrm{~mm}$, and $1500 \mathrm{~mm}$ in Wulong, respectively. Using (1), (2), and (3), the injection 

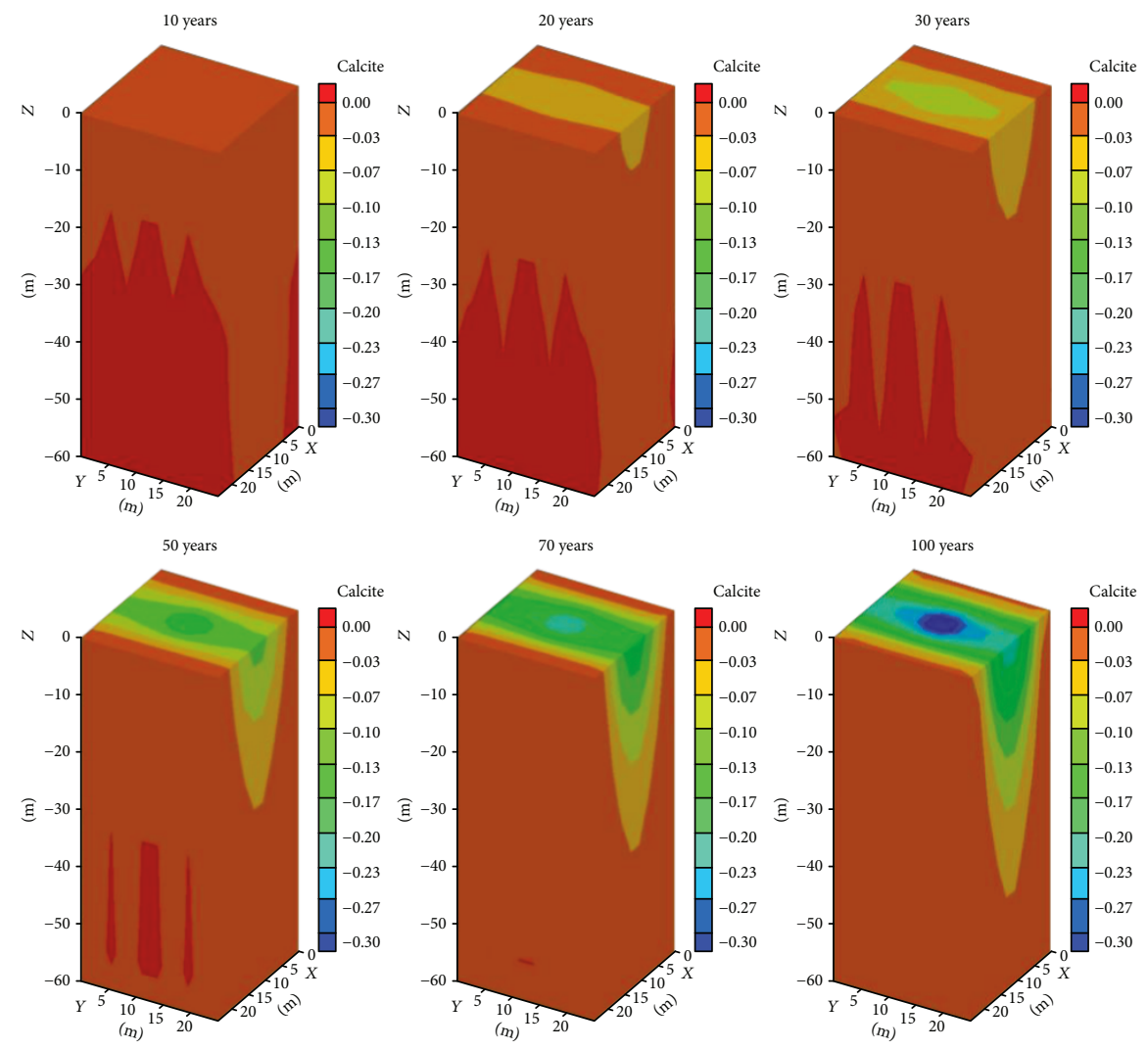

FIgURE 7: The corrosion range of the fissure under medium hydrodynamic conditions-medium permeability- $10^{\circ} \mathrm{C}$.

flow rates of the weak hydrodynamic condition (a), the middle hydrodynamic condition (b), and the strong hydrodynamic condition (c) were calculated to be $1.9 \mathrm{~kg} / \mathrm{s}, 2.9 \mathrm{~kg} / \mathrm{s}$, and $3.9 \mathrm{~kg} / \mathrm{s}$, respectively. There were 54 different conditions considered to evaluate the evolution of fissure corrosion (Table 4).

The simulation software used in this study was TOUGHREACT, which is widely used in the numerical simulation of water-rock interactions $[66,67]$.

\section{Results and Discussion}

4.1. Corrosion Range under Different Conditions. The conditions of medium hydrodynamics and medium permeability were taken as examples (case 7(b) case 12(b)) with which the corrosion process of fissures under different temperatures was analyzed (Figures 7-9). By comparing Figure 7 with Figure 9, during the same corrosion time, the corrosion range of $35^{\circ} \mathrm{C}$ was larger than that of $10^{\circ} \mathrm{C}$. After 100 years of corrosion, the horizontal and vertical corrosion ranges of $35^{\circ} \mathrm{C}$ were 1.2 times and 1.3 times higher than those of $10^{\circ} \mathrm{C}$, respectively.

The condition of medium hydrodynamics and the temperature of $20^{\circ} \mathrm{C}$ were taken as examples (case $3(\mathrm{~b})$, case 9(b), and case 15(b)) with which the corrosion process of tunnel fractures under different porosity and permeability conditions was analyzed (Figures 10-12). By comparing Figure 10 with Figure 12, during the same corrosion time, the corrosion range of high-porosity and high-permeability conditions was larger than that of low-porosity and lowpermeability conditions. After 100 years of corrosion, the horizontal and vertical corrosion ranges of high-porosity and high-permeability conditions were 1.4 times and 1.6 times higher than those of low-porosity and low-permeability conditions, respectively.

The conditions of $20^{\circ} \mathrm{C}$ and medium permeability were taken as examples (case 9(a), case 9(b), and case 9(c)) with which the corrosion process of the tunnel fissure under different flow rates was analyzed (Figures 13-15). By comparing Figure 13 with Figure 15, during the same corrosion time, the corrosion range of the strong hydrodynamic condition was larger than that of the weak hydrodynamic condition. After 100 years of corrosion, the corrosion ranges of the strong hydrodynamic condition were 1.8 times and 2.2 times higher than those of the weak hydrodynamic condition, respectively.

4.2. Corrosion Ratios under Different Conditions. Taking the high-porosity/permeability (case 1 case 6) and lowporosity/permeability conditions (case 13 case 18) as examples, we analyzed the corrosion ratios of the tunnel fissure under different flow rates and temperatures (Figures 16(a) and 17(b)). From Figures 16(a) and 17(b), we can see that the corrosion ratio increased with the time of corrosion. During the same corrosion time, the higher the temperature, the greater the corrosion ratio. After 100 years of corrosion, the corrosion ratio (strong hydrodynamic condition and high porosity and permeability) of $35^{\circ} \mathrm{C}(0.4032 \%)$ was 1.2 times higher than that of $10^{\circ} \mathrm{C}(0.3369 \%)$. 

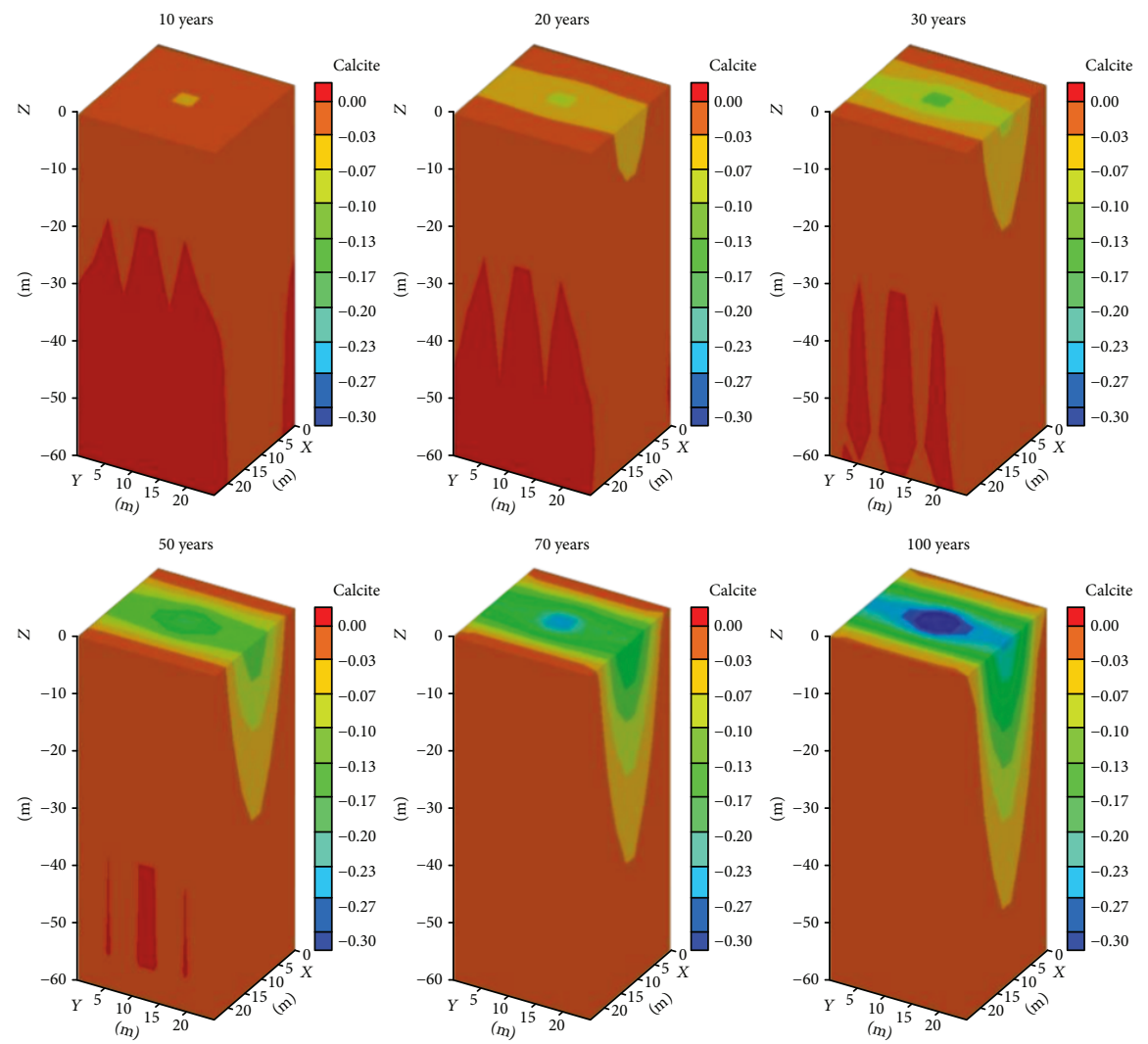

FigURE 8: The corrosion range of the fissure under medium hydrodynamic conditions-medium permeability- $20^{\circ} \mathrm{C}$.
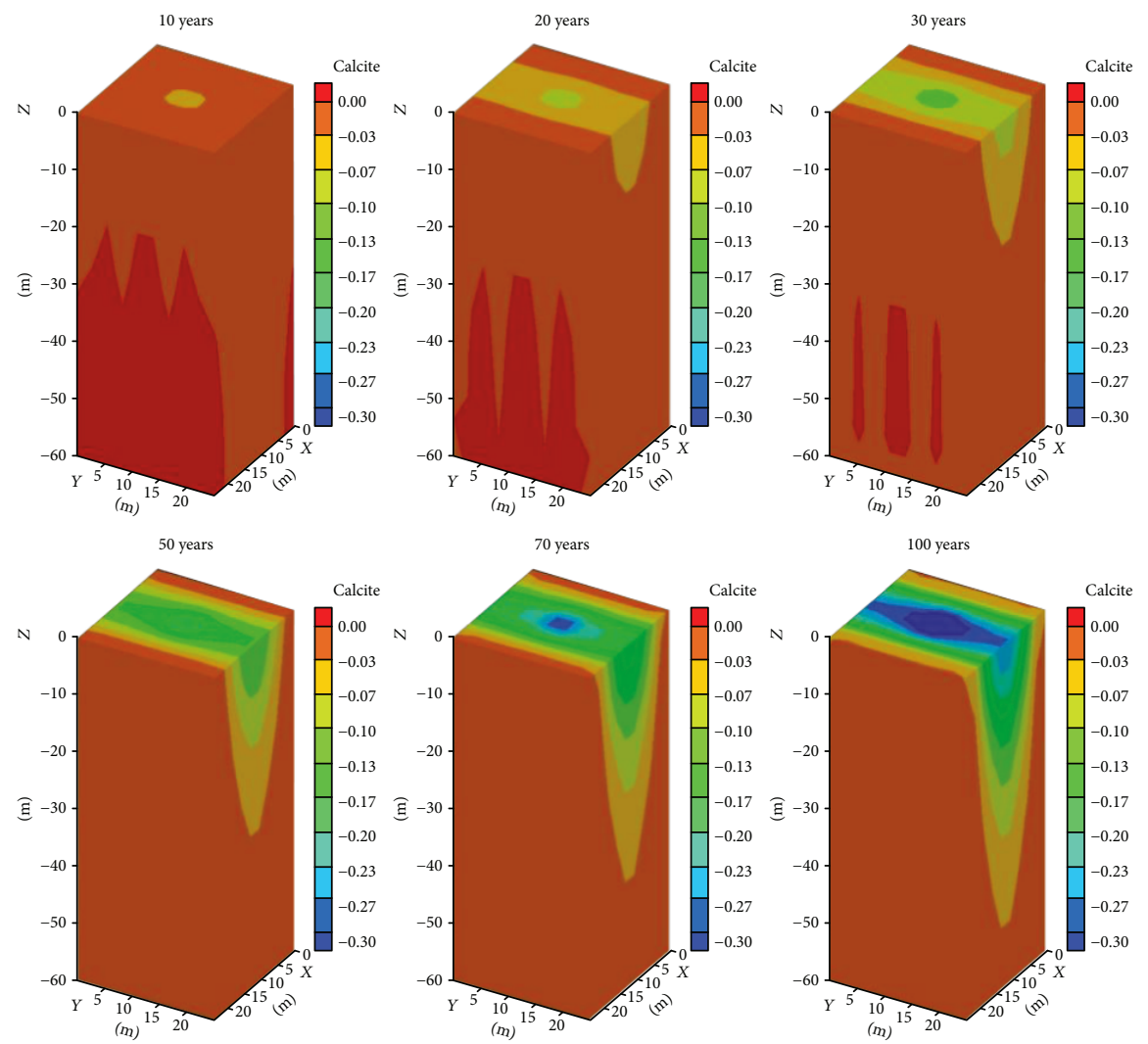

FigurE 9: The corrosion range of the fissure under medium hydrodynamic conditions-medium permeability- $35^{\circ} \mathrm{C}$. 

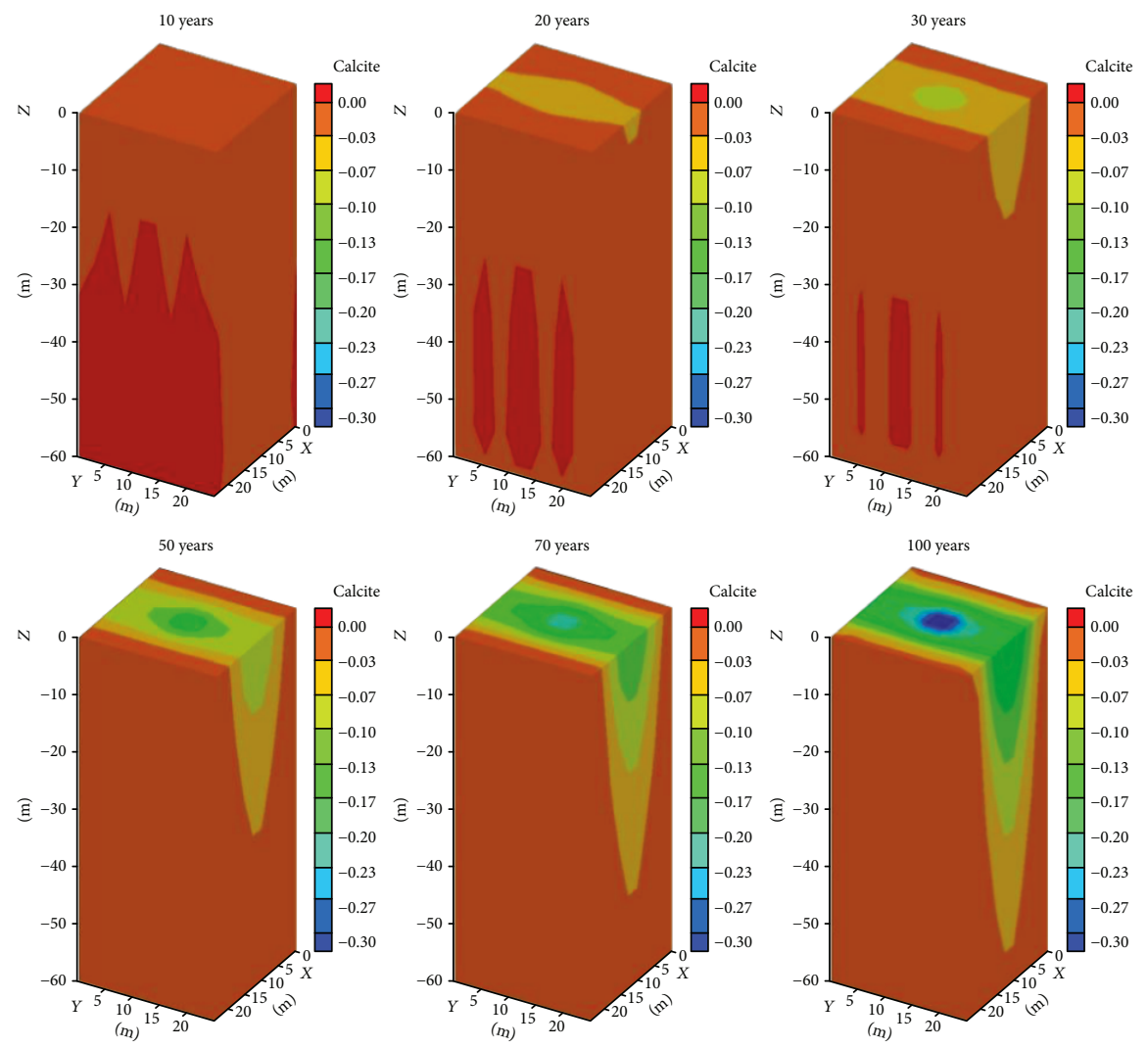

Figure 10: The corrosion range of the fissure under medium hydrodynamic conditions-low permeability- $20^{\circ} \mathrm{C}$.
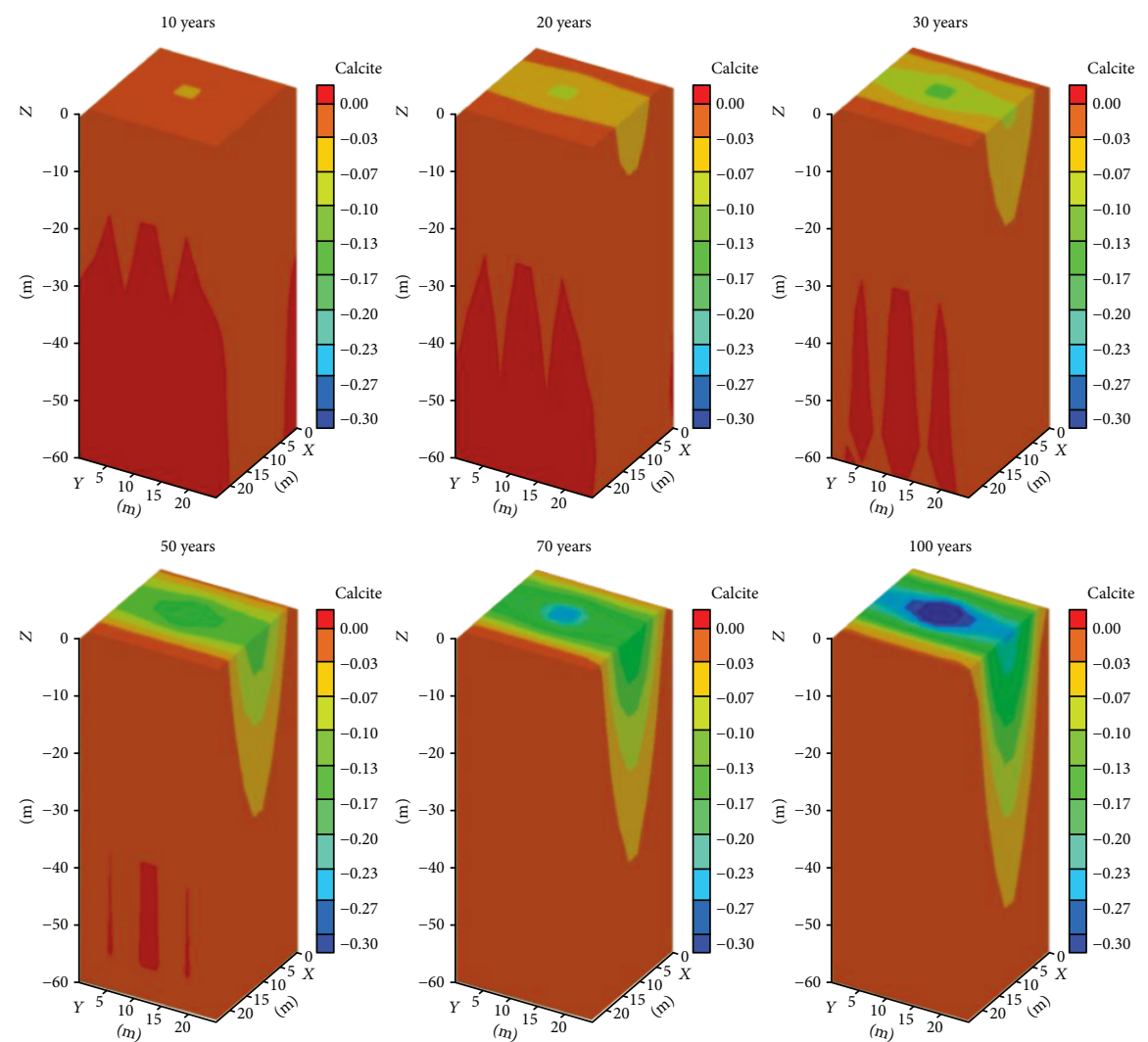

Figure 11: The corrosion range of the fissure under medium hydrodynamic conditions-medium permeability $-20^{\circ} \mathrm{C}$. 

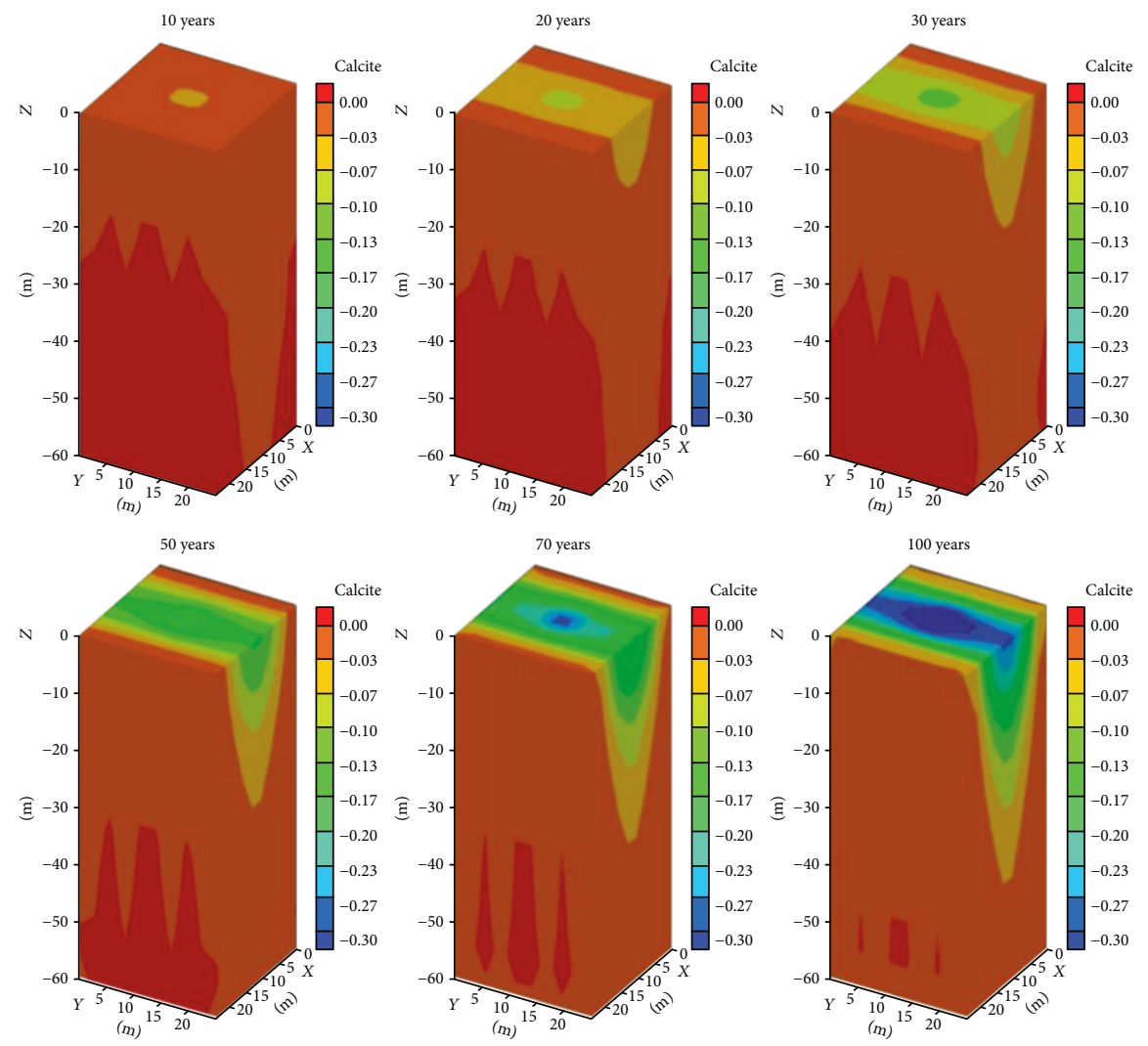

FIGURE 12: The corrosion range of the fissure under medium hydrodynamic conditions-high permeability $-20^{\circ} \mathrm{C}$.
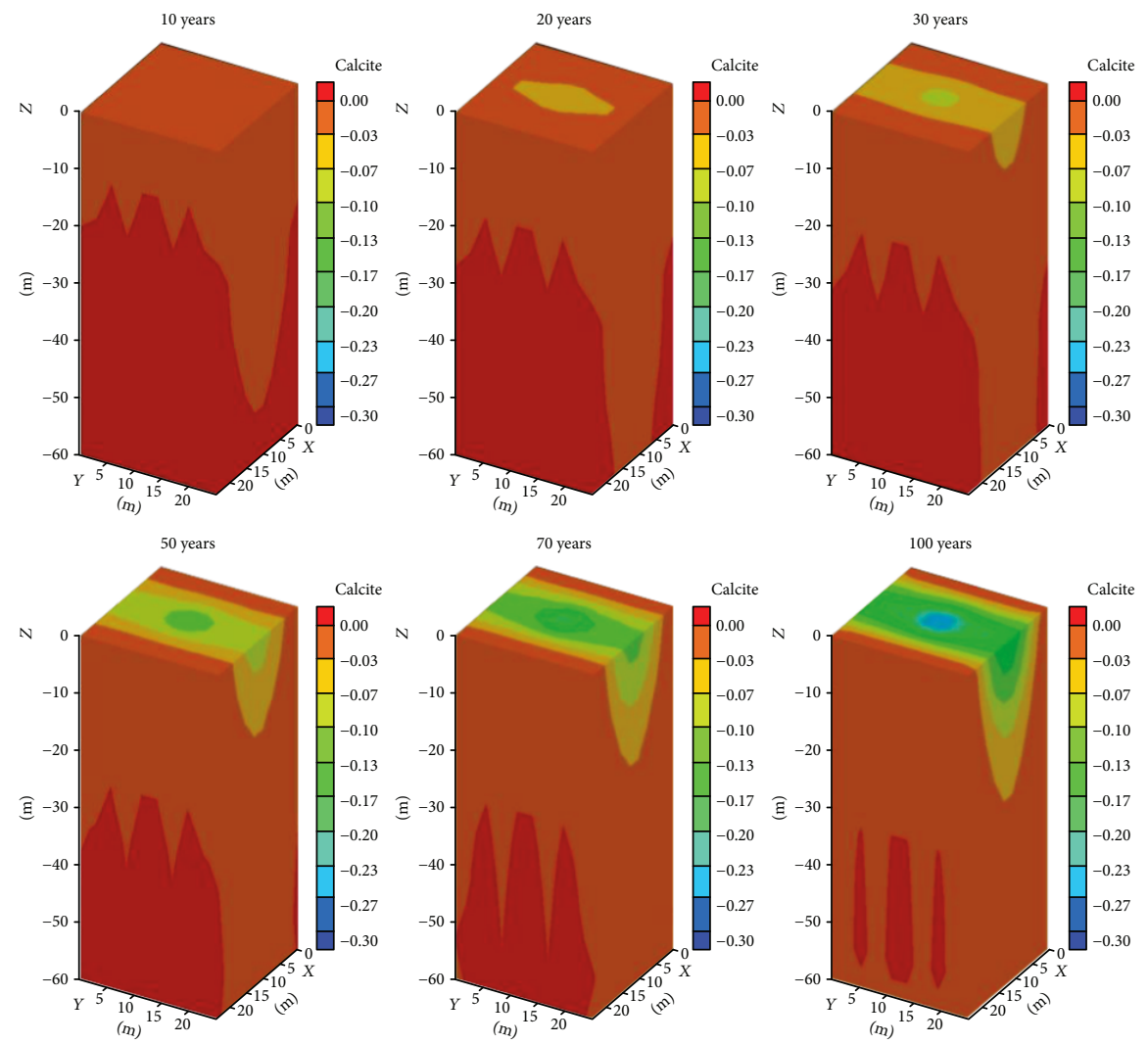

FIgURE 13: The corrosion range of the fissure under weak hydrodynamic conditions-medium permeability-20 $0^{\circ}$. 

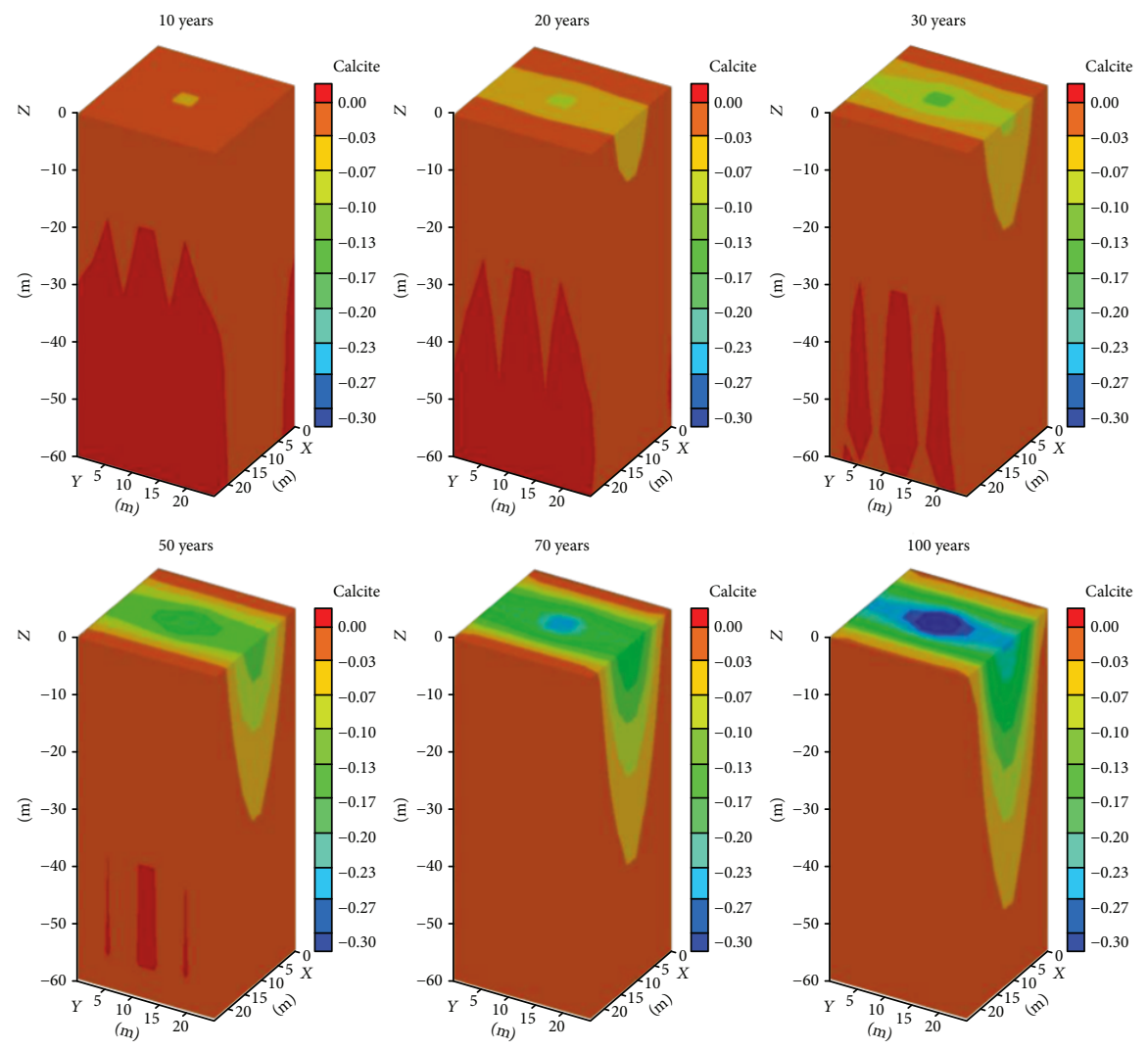

FIGURE 14: The corrosion range of the fissure under medium hydrodynamic conditions-medium permeability-20 $\mathrm{C}$.
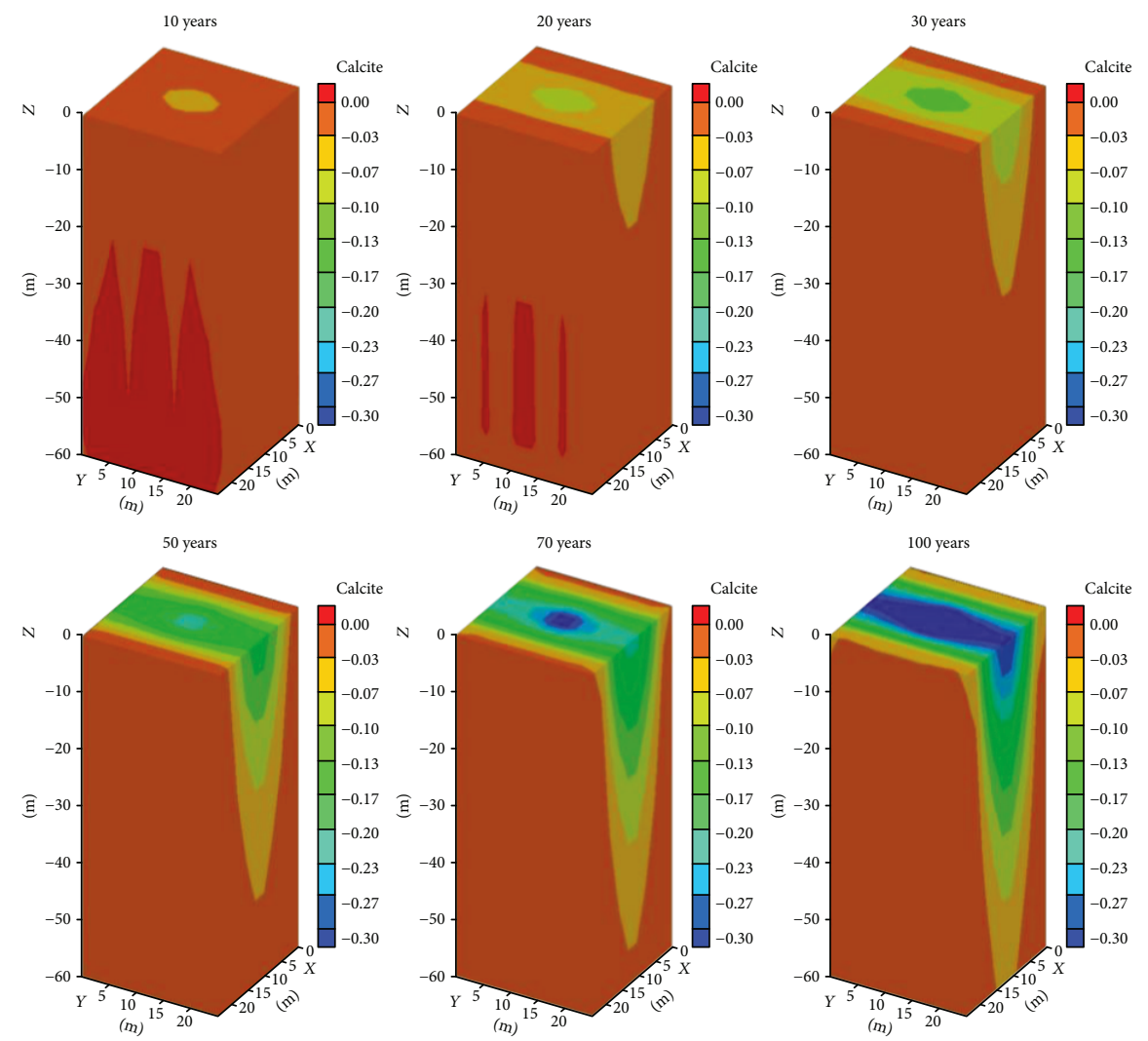

FIgURE 15: The corrosion range of the fissure under strong hydrodynamic conditions-medium permeability $-20^{\circ} \mathrm{C}$. 


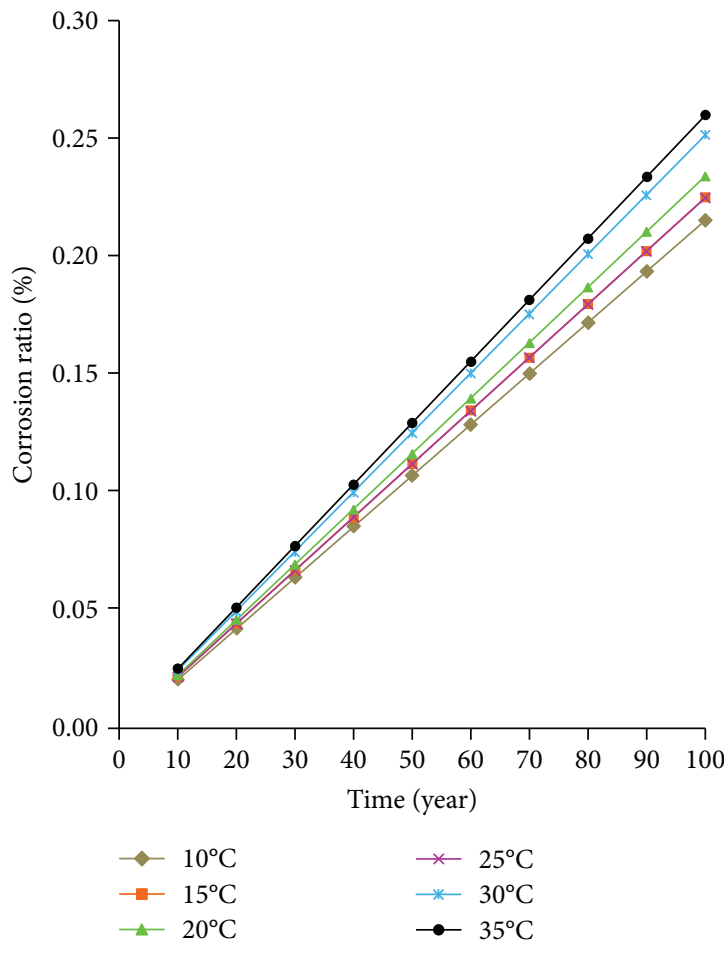

(a) Low permeability

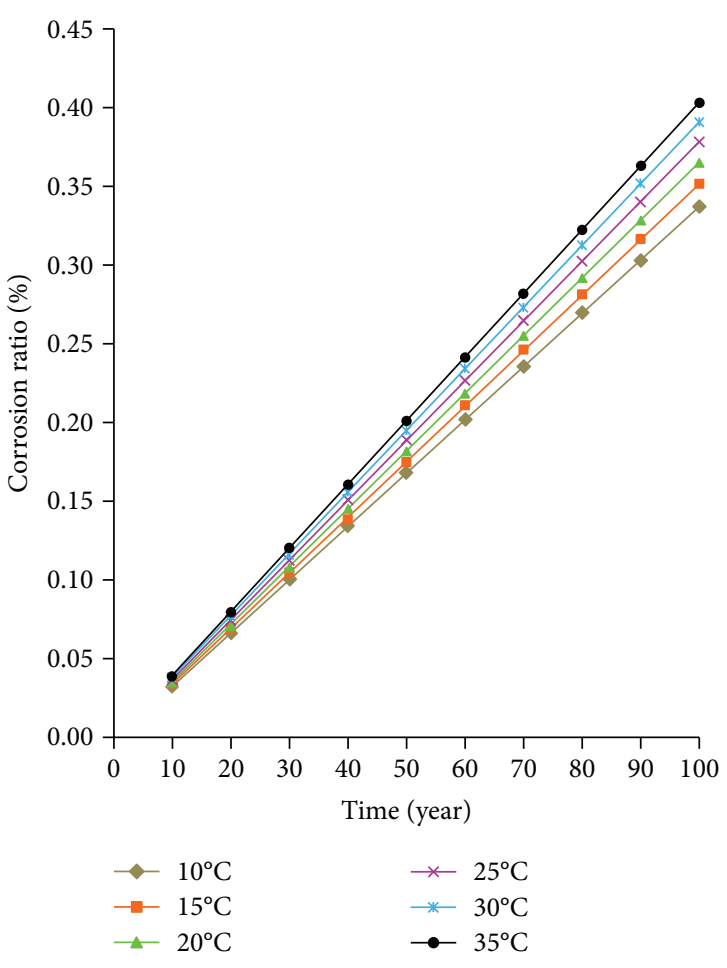

(b) High permeability

FIgURE 16: The corrosion ratio of the fissure under strong hydrodynamic conditions over time.

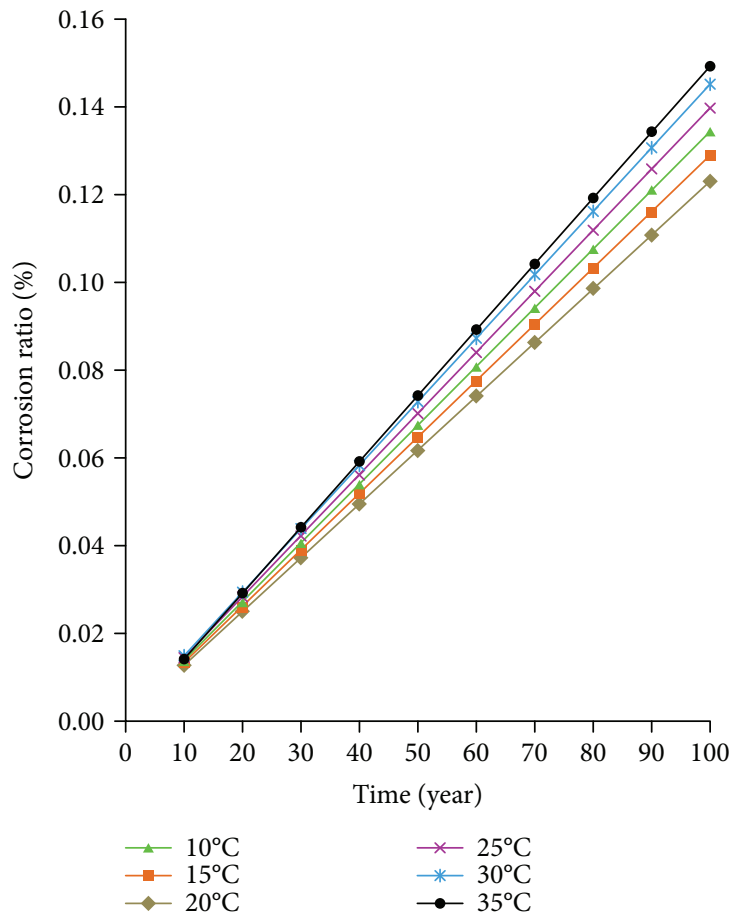

(a) Low permeability

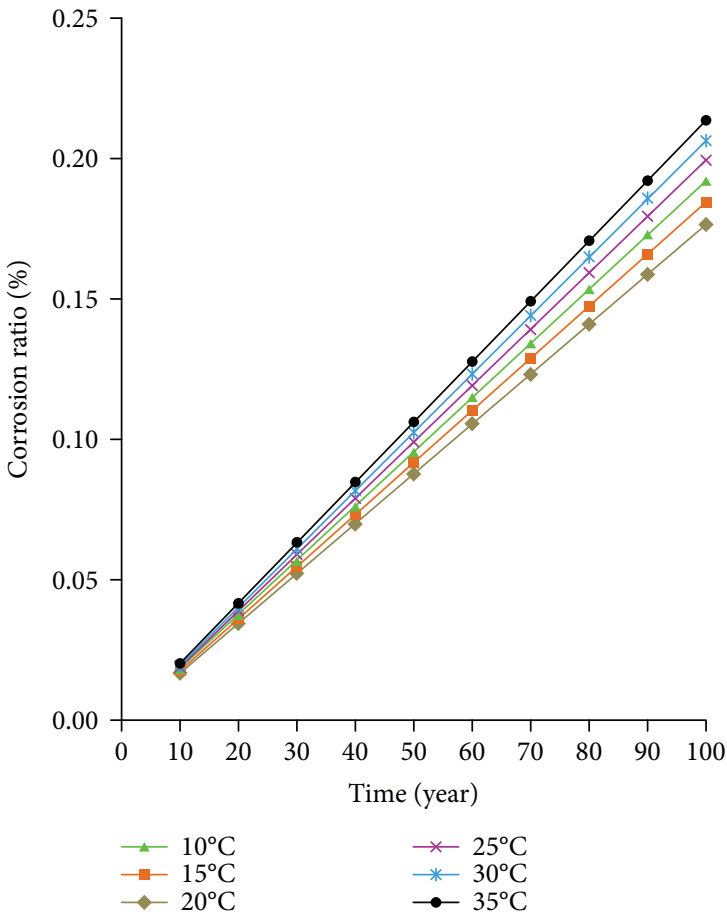

(b) High permeability

FiguRE 17: The corrosion ratio of the fissure under weak hydrodynamic conditions over time.

The comparisons of Figure 16(a) with Figure 16(b) and Figure 17(a) with Figure 17(b), during the same corrosion time, reveal that the corrosion ratio of the tunnel fissure under the high-permeability condition $\left(7.4 \times 10^{-10} \mathrm{~m}^{2}\right)$ was greater than that under the low-permeability condition $\left(7.4 \times 10^{-12} \mathrm{~m}^{2}\right)$. After 100 years of corrosion, the corrosion 

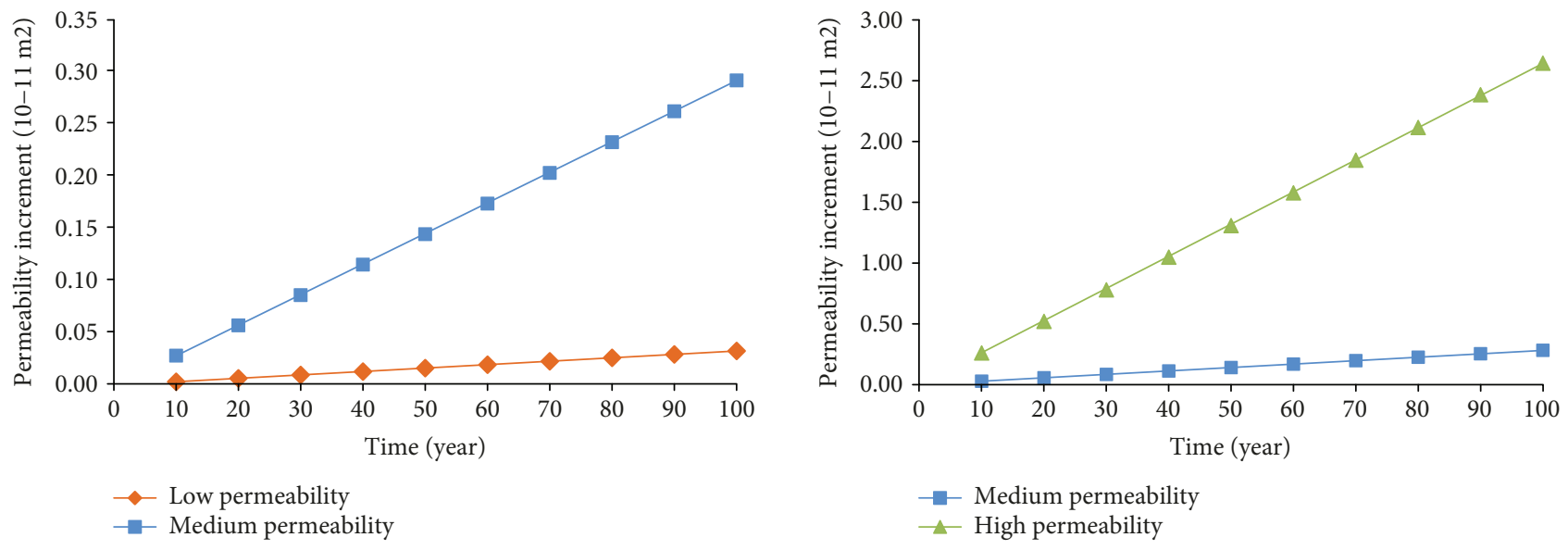

FIGURE 18: The rate of increase of permeability over time.

ratio (strong hydrodynamic condition, $35^{\circ} \mathrm{C}$, and high porosity and permeability) $(0.4032 \%)$ was 1.6 times higher than that of low porosity and permeability $(0.2599 \%)$.

The comparison of Figure 16(a) with Figure 17(a) and Figure 16(b) with Figure 17(b), during the same corrosion time, reveals that under strong hydrodynamic conditions, the corrosion ratio was greater than that under the weak hydrodynamic condition. After 100 years of corrosion, the maximum corrosion ratio $(0.4032 \%)$ under the strong hydrodynamic conditions (high porosity and permeability, $35^{\circ} \mathrm{C}$ ) was 2.1 times than that under the weak hydrodynamic condition $(0.1908 \%)$.

4.3. Evolution of Porosity and Permeability in the Fissure Zone. The structure of the fissures in soluble rock of karst areas is the foundation of the corrosion. The porosity and permeability conditions in fissure zones are the main factors affecting the development of karst. Through the analysis of the effects of different temperatures and flow rates on corrosion, it was found that the most significant corrosion occurred at the temperature of $35^{\circ} \mathrm{C}$ and strong hydrodynamic conditions. Therefore, we selected $35^{\circ} \mathrm{C}$ and strong hydrodynamic conditions as an example with which the variation of the porosity and permeability of the fissure zone within 100 years was discussed.

According to the simulation results of 10-100 years of corrosion, the porosity and permeability changes in the fracture core zone of the karst development area were obtained. The relation curves of the increase of permeability with time are shown in Figure 18. As shown in Figure 18, the rate of change of permeability also increased with time. Permeability increased much faster under the condition of high permeability than under the condition of low permeability. After 100 years of corrosion, the permeability increased from $7.40 \times 10^{-12} \mathrm{~m}^{2}$ to $7.73 \times 10^{-12} \mathrm{~m}^{2}$; the maximum increase of permeability was $0.33 \times 10^{-12} \mathrm{~m}^{2}$ under the low-permeability condition. Meanwhile, under the high-permeability condition, the permeability increased from $740.00 \times 10^{-12} \mathrm{~m}^{2}$ to $767.5 \times 10^{-12} \mathrm{~m}^{2}$ and the maximum increase of permeability was $27.5 \times 10^{-12} \mathrm{~m}^{2}$. It was
83.3 times higher than that under the low-permeability condition.

As shown in Figure 19, under the conditions of different porosities, the porosity increased with the corrosion time (linear relationship). Under the condition of high porosity, porosity increased much faster than that under the lowporosity condition. After 100 years of corrosion, the porosity of the low-porosity condition increased from 0.200 to 0.203 , while under the high-porosity condition, the porosity increased from 0.350 to 0.354 . The maximum increase of porosity under the high-porosity condition was 2 times higher than that under the low-porosity condition.

The reasons for the changes in the corrosion range, porosity, and permeability of the fissure zone are discussed as follows:

The lithology of the study area is carbonate rocks comprising 95\% calcite; the corrosion of carbonate rocks was mainly caused by calcite corrosion, and the chemical reaction equations are as follows:

$$
\begin{aligned}
\mathrm{CO}_{2}(\mathrm{~g})+\mathrm{H}_{2} \mathrm{O} & \rightleftharpoons \mathrm{CO}_{2}(\mathrm{aq})+\mathrm{H}_{2} \mathrm{O} \\
\mathrm{H}_{2} \mathrm{CO}_{3} & \rightleftharpoons \mathrm{H}^{+}+\mathrm{HCO}_{3}{ }^{-} \\
\mathrm{HCO}_{3}{ }^{-} & \rightleftharpoons \mathrm{H}^{+}+\mathrm{CO}_{3}{ }^{2-} \\
\mathrm{H}_{2} \mathrm{O} & \rightleftharpoons \mathrm{H}^{+}+\mathrm{OH}^{-} \\
\mathrm{OH}^{-}+\mathrm{CO}_{2}(\mathrm{aq}) & \rightleftharpoons \mathrm{HCO}_{3}^{-} \\
\mathrm{CaCO}_{3}+\mathrm{H}^{+} & \rightleftharpoons \mathrm{CaHCO}_{3}^{+} \\
\mathrm{CaHCO}_{3}{ }^{+} & \rightleftharpoons \mathrm{Ca}^{2+}+\mathrm{HCO}_{3}{ }^{-} \\
\mathrm{CaCO}_{3} & \rightleftharpoons \mathrm{Ca}^{2+}+\mathrm{CO}_{3}{ }^{2-}
\end{aligned}
$$

Because calcite corrosion's chemical balance will be affected by temperature, in the range of simulated temperatures $\left(10^{\circ} \mathrm{C} \sim 35^{\circ} \mathrm{C}\right)$, the reaction rate constant increased with temperature, causing the reaction's equilibrium to move towards the direction of the solution. These results have the same corrosion trend as those obtained by Pokrovsky et al. [23] and Huang [68]. They used an experimental method to 


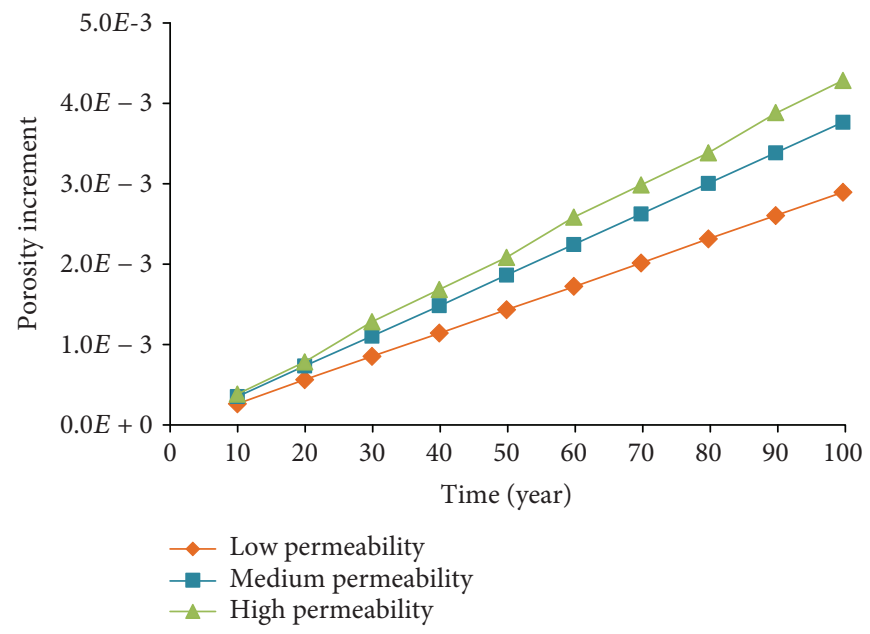

FIgURE 19: The increase of porosity over time.

explore corrosion under neutral conditions and different temperatures $\left(0.5^{\circ} \mathrm{C} \sim 40^{\circ} \mathrm{C}\right)$.

According to (4), during the corrosion of calcite, $\mathrm{Ca}^{2+}$ was the main product of the chemical reaction. Under weak hydrodynamic conditions, the flow through the fissures was less and the travel time of water through the fissures was longer. Therefore, the concentration of dissolved $\mathrm{Ca}^{2+}$ was higher in the water, and when the water flow reached the lower part of the fissure, the concentration of $\mathrm{Ca}^{2+}$ in the water was close to saturation. Therefore, corrosion mainly occurred in the upper part of the fissure under the weak hydrodynamic condition, and the corrosion ratio was relatively small. In contrast, in the strong hydrodynamic conditions, the flow rate through the fissures was faster and the travel time of water through the fissures was shorter than that under the weak hydrodynamic condition. Therefore, the concentration of dissolved $\mathrm{Ca}^{2+}$ was lower in water under the strong hydrodynamic condition, and when the water seepage reached the lower part of the fracture, the concentration of $\mathrm{Ca}^{2+}$ was lower. The resulting corrosion of the fissures was more obvious than that of those in the weak hydrodynamic condition, and the corrosion range runs through the whole fissure with a higher corrosion ratio. In addition, due to the increased flow rate, the mechanical failure of the rock is enhanced, which makes the surface of the rock broken. The rock powder on the broken surface of the rock was carried away by the water, thus increasing the corrosion ratio and corrosion range.

Under the conditions of high porosity and permeability, the porosity and permeability increased faster than those under the low-porosity and low-permeability condition. After 100 years of corrosion, the permeability change under the high-permeability condition was 83.3 times higher than that under the low-permeability condition, while the change of porosity under the high-permeability condition was only 2 times higher than that under the low-permeability condition. It can be speculated that with continuing corrosion, more and more dead-end pores became effective pores. Due to the transformation of dead-end pores into effective pores, the connectivity between pores was significantly enhanced

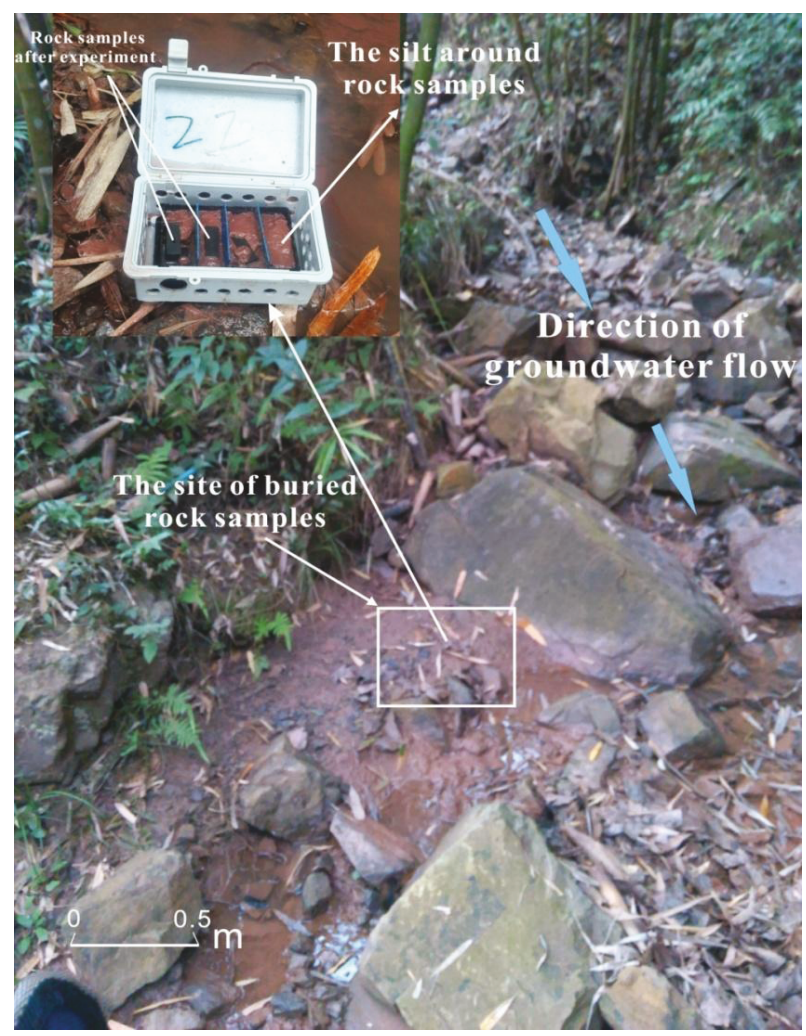

FIgURE 20: The site of the field experiment.

and the increase of fissure permeability became significantly larger, while the porosity increased only slightly. Therefore, the degree of change in permeability was much greater than that in porosity in the same period.

According to the simulation results, the larger the porosity and permeability were, the more significant the increases in porosity and permeability were, which led to the enhancement of corrosion in the high-porosity and high-permeability zones and enhancement the differential corrosion of karst. 


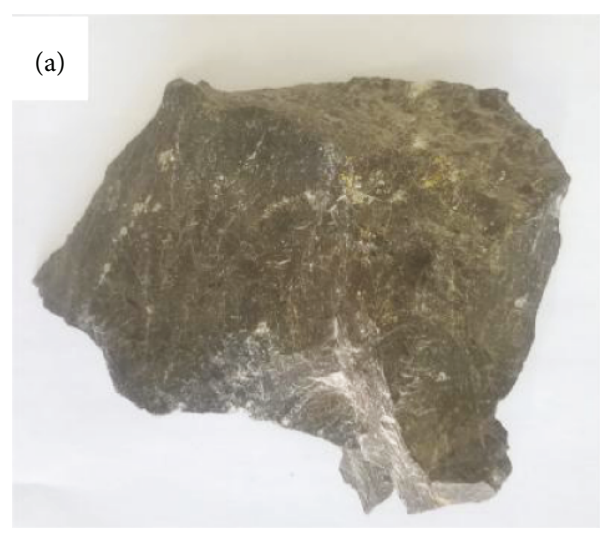

(a)

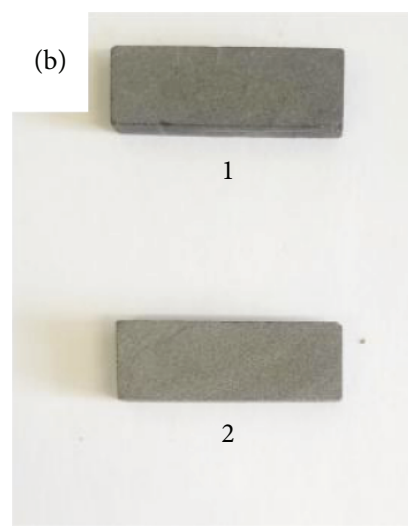

(b)

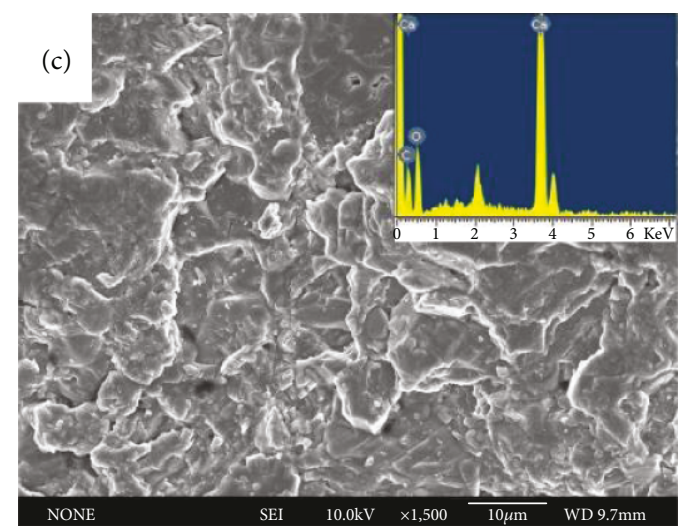

(c)

Figure 21: Rock samples. (a) Original experimental samples, (b) rock samples after being cut, and (c) SEM photograph $(\times 1500)$.

\section{Comparison of the Field Corrosion Experiment Results to the Numerical Simulation Results}

To further explore the corrosion characteristics of rock samples at the tunnel's key karst development parts and verify the reliability of the simulation results, a field corrosion experiment was carried out. The field experimental site was a gully in the Wulong tunnel construction area, which is in the key development parts of the tunnel karst area. The width of the gully is approximately 2.5 meters (Figure 20), and the lithology of the underlayer stratum is thick-layer limestone. The gully is covered with clay, gravel, and plants. The burial depth of groundwater was small.

The experimental rock samples were made of the limestone of the Changxing Formation, with a size of $30 \mathrm{~mm} \times 10 \mathrm{~mm} \times 10 \mathrm{~mm}$ (Figure 21(b)). The rock samples were placed into a plastic box with holes that allowed groundwater to flow through it. The plastic box was buried underground below the groundwater level (Figures 20 and 22).

After one year of corrosion, the box was taken out and the degrees of corrosion of the rock samples (Figure 20) were measured. Because the corrosion of rock samples depends on the surface area of the water-rock

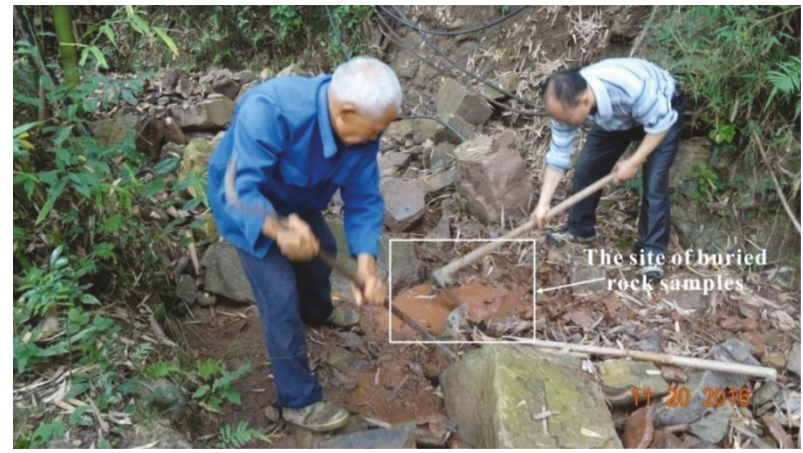

Figure 22: The process of the field experiment.

interaction, we used (5) to calculate the surface corrosion ratio $R\left(\mathrm{~g} /\left(\mathrm{m}^{2} \cdot \mathrm{a}\right)\right)$.

$$
R=\frac{m}{s^{*} t}
$$

where $R=m / s t$ is the corrosion ratio of the unit area $\left(\mathrm{g} /\left(\mathrm{m}^{2} \cdot \mathrm{a}\right)\right)$ ; $s$ is the surface area of the water-rock interaction $\left(\mathrm{m}^{2}\right) ; t$ is the corrosion time (a).

For numerical simulation, according to Figures 16(a) and 17 (b), the corrosion ratio showed a linear variation with time. The corrosion ratio (after one year of corrosion) was obtained by linear interpolation; then, the surface corrosion 
TABLE 5: The surface corrosion ratios of the field experiment and numerical simulation.

\begin{tabular}{|c|c|c|c|c|}
\hline Corrosion condition & & Before corrosion (g) & Corrosion amount (g) & $\begin{array}{l}\text { Surface corrosion } \\
\text { ratio }\left(\mathrm{g} /\left(\mathrm{m}^{2} \cdot \mathrm{a}\right)\right)\end{array}$ \\
\hline \multirow{2}{*}{ Field experiment } & Field experiment (1) & 8.5940 & 0.0033 & 2.3571 \\
\hline & Field experiment (2) & 8.4638 & 0.0037 & 2.6429 \\
\hline \multirow{9}{*}{ Numerical simulation } & $\begin{array}{l}\text { Strong hydrodynamic condition-high } \\
\text { permeability }\left(20^{\circ} \mathrm{C}\right)\end{array}$ & $8.0870 \times 10^{4}$ & 2.8604 & 9.9319 \\
\hline & $\begin{array}{l}\text { Strong hydrodynamic condition-medium } \\
\text { permeability }\left(20^{\circ} \mathrm{C}\right)\end{array}$ & $8.2598 \times 10^{4}$ & 2.5292 & 8.7818 \\
\hline & $\begin{array}{l}\text { Strong hydrodynamic condition-low } \\
\text { permeability }\left(20^{\circ} \mathrm{C}\right)\end{array}$ & $8.4326 \times 10^{4}$ & 1.9142 & 6.6466 \\
\hline & $\begin{array}{l}\text { Medium hydrodynamic condition-high } \\
\text { permeability }\left(20^{\circ} \mathrm{C}\right)\end{array}$ & $8.0870 \times 10^{4}$ & 2.2369 & 7.7669 \\
\hline & $\begin{array}{l}\text { Medium hydrodynamic condition-medium } \\
\text { permeability }\left(20^{\circ} \mathrm{C}\right)\end{array}$ & $8.2598 \times 10^{4}$ & 2.0014 & 6.9492 \\
\hline & $\begin{array}{l}\text { Medium hydrodynamic condition-low } \\
\text { permeability }\left(20^{\circ} \mathrm{C}\right)\end{array}$ & $8.4326 \times 10^{4}$ & 1.5440 & 5.3612 \\
\hline & $\begin{array}{l}\text { Weak hydrodynamic condition-high } \\
\text { permeability }\left(20^{\circ} \mathrm{C}\right)\end{array}$ & $8.0870 \times 10^{4}$ & 1.4678 & 5.0965 \\
\hline & $\begin{array}{l}\text { Weak hydrodynamic condition-medium } \\
\text { permeability }\left(20^{\circ} \mathrm{C}\right)\end{array}$ & $8.2598 \times 10^{4}$ & 1.3356 & 4.6376 \\
\hline & $\begin{array}{c}\text { Weak hydrodynamic condition-low } \\
\text { permeability }\left(20^{\circ} \mathrm{C}\right)\end{array}$ & $8.4326 \times 10^{4}$ & 1.0667 & 3.7039 \\
\hline
\end{tabular}

ratio $\left(\mathrm{g} /\left(\mathrm{m}^{2} \cdot \mathrm{a}\right)\right)$ was calculated with $(5)$. The surface corrosion ratios of rock samples per unit area in the field experiment and numerical simulation are listed in Table 5.

From Table 5, we can see that the surface corrosion ratio of rock samples in the field experiments was less than that in the numerical simulation. The surface corrosion ratio of the weak hydrodynamic condition (numerical simulation) was close to that of the field experiments. Analyzing the hydrogeological conditions of the field experiment and the setting of hydrogeological conditions in numerical simulation, the water flow in the numerical simulation was mainly in the fracture core and the flow rates were faster than those in the field experiments. Thus, in the strong hydrodynamic condition and medium hydrodynamic condition, the surface corrosion ratios obtained in the simulation were higher than those obtained in the field experiment. However, overall, the differences in the corrosion ratio between the numerical simulation and field experiment were on the same order of magnitude. Therefore, the results of the numerical simulation model were reliable, and the model can be used to predict the corrosion evolution of the fissures in soluble rock of the tunnel in the future.

\section{Conclusion}

In this study, the numerical simulation model of the fissures in soluble rock of karst areas of the Wulong tunnel was established, and the corrosion characteristics of the fissures were evaluated. The conclusions were as follows:

(1) The development of the fissures in soluble rock of karst areas of the tunnel was mostly affected by the flow rates. After 100 years of corrosion, under the influence of temperature and porosity and permeability, the maximum corrosion range and corrosion ratio were only 1.2 times 1.6 times higher than the minimum values, respectively. In contrast, the corrosion range of the strong hydrodynamic condition was approximately 1.8 times $\sim 2.2$ times higher than that of the weak hydrodynamic condition, and the corrosion ratio of the strong hydrodynamic condition was 2.1 times higher than that of the weak hydrodynamic condition.

(2) In the temperature range of $10^{\circ} \mathrm{C} \sim 35^{\circ} \mathrm{C}$, the corrosion range and the corrosion ratio were proportional to the temperature because the reaction rate constant increased with temperature, causing the reactions' equilibria to move towards the direction of the solution. After 100 years of corrosion, the corrosion ranges of $35^{\circ} \mathrm{C}$ were 1.2 times 1.3 times higher than those of $10^{\circ} \mathrm{C}$, and the corrosion ratio of $35^{\circ} \mathrm{C}$ was 1.2 times higher than that of $10^{\circ} \mathrm{C}$.

(3) The porosity and permeability of the fissure zone enhanced the corrosion of the fissure and enhanced the differential corrosion of karst. The higher the porosity and permeability were, the more significant the enhancement effects on the porosity and permeability were. Many of the dead-end pores became effective pores, which greatly increased the permeability, but the slightly increased porosity also accelerated the corrosion damage of the tunnel.

(4) The simulation results were verified by the field experiment, and the simulation model can be used 
to quantitatively predict the corrosion evolution of a fissure zone within the acceptable range of error.

\section{Data Availability}

The data used to support the findings of this study are available from the corresponding author upon request.

\section{Conflicts of Interest}

The authors declare no conflict of interest.

\section{Acknowledgments}

This work was supported by the Graduate Innovation Fund of Jilin University (no. 2017148), the National Natural Science Foundation of China (no. 41372334), and the China National Science and Technology Major Project (no. 2016ZX05016-005).

\section{References}

[1] D. T. Li and Y. Luo, "Measurement of carbonate rocks distribution area in China," Carsologica Sinica, vol. 2, pp. 147150, 1983.

[2] C. S. Li, J. F. Ding, and Y. K. Liao, Geochemical Dynamics and Fractal Features of Karst Tunnel, The Science Publishing Company, Beijing, China, 2017.

[3] F. Gutierrez, "Hazards associated with karst," in Geomorphological Hazards and Disaster Prevention, I. Alcantara-Ayala and A. S. Goudie, Eds., pp. 161-176, Cambridge University Press, Cambridge, UK, 2010.

[4] F. Gutierrez, M. Parise, J. De Waele, and H. Jourde, "A review on natural and human-induced geohazards and impacts in karst," Earth Science Reviews, vol. 138, pp. 61-88, 2014.

[5] M. Parise and J. Gunn, Eds., Natural and Anthropogenic Hazards in Karst Areas: Recognition, Analysis and Mitigation, Geological Society Special Publication 279, London, UK, 2007.

[6] M. Parise, D. Closson, F. Gutierrez, and Z. Stevanovic, "Anticipating and managing engineering problems in the complex karst environment," Environmental Earth Sciences, vol. 74, no. 12, pp. 7823-7835, 2015.

[7] X. Q. Qin, M. Q. Zhu, and Z. C. Jiang, "A review on recent advances in rocky desertification in Southwest China karst region," Carsologica Sinica, vol. 25, pp. 234-238, 2006.

[8] Y. Wang, The Karst Water Accumulation Law in the Faulted Basin, Science and Technology Press, Kunming, China, 2003.

[9] C. S. Li, B. Gao, and Z. R. Mei, Karst and Groundwater Advance Prediction Techniques, Southwest Jiaotong University Press, Chengdu, China, 2013.

[10] S. C. Li, Z. Q. Zhou, L. P. Li, Z. H. Xu, Q. Q. Zhang, and S. S. Shi, "Risk assessment of water inrush in karst tunnels based on attribute synthetic evaluation system," Tunnelling and Underground Space Technology, vol. 38, pp. 50-58, 2013.

[11] A. C. Waltham and P. G. Fookes, "Engineering classification of karst ground conditions," Quarterly Journal of Engineering Geology and Hydrogeology, vol. 36, no. 2, pp. 101-118, 2003.

[12] R. S. Arvidson, C. Fischer, and A. Luttge, "Calcite dissolution kinetics," Aquatic Geochemistry, vol. 21, no. 5, pp. 415-422, 2015.
[13] D. Buhmann and W. Dreybrodt, "Calcite dissolution kinetics in the system $\mathrm{H}_{2} \mathrm{O} \cdot \mathrm{CO}_{2} \cdot \mathrm{CaCO}_{3}$ with participation of foreign ions," Chemical Geology, vol. 64, no. 1-2, pp. 89-102, 1987.

[14] W. Dreybrodt, F. Gabrovšek, and D. Romanov, Processes of Speleogenesis: A Modeling Approach, Karst Research Institute, ZRC SAZU, Postojna, Slovenia, 2005.

[15] L. Eisenlohr, K. Meteva, F. Gabrovšek, and W. Dreybrodt, "The inhibiting action of intrinsic impurities in natural calcium carbonate minerals to their dissolution kinetics in aqueous $\mathrm{H}_{2} \mathrm{O}-\mathrm{CO}_{2}$ solutions," Geochimica et Cosmochimica Acta, vol. 63, no. 7-8, pp. 989-1001, 1999.

[16] F. Gabrovšek and M. Ž. Huzjan, Evolution of Early Karst Aquifers: From Simple Principles to Complex Models, Zalozba ZRC, Ljubljana, Slovenia, 2000.

[17] T. Hiller, D. Romanov, G. Kaufmann, J. Epting, and P. Huggenberger, "Karstification beneath the Birs weir in Basel/Switzerland: a 3D modeling approach," Journal of Hydrology, vol. 448-449, pp. 181-194, 2012.

[18] A. A. Jeschke and W. Dreybrodt, "Pitfalls in the determination of empirical dissolution rate equations of minerals from experimental data and a way out: an iterative procedure to find valid rate equations, applied to Ca-carbonates and -sulphates," Chemical Geology, vol. 192, no. 3-4, pp. 183-194, 2002.

[19] A. C. Lasaga, Kinetic Theory in the Earth Sciences, Princeton University Press, Princeton, NJ, USA, 2014.

[20] J. W. Morse and R. A. Berner, "Dissolution kinetics of calcium carbonate in sea water; I, A kinetic origin for the lysocline," American Journal of Science, vol. 272, no. 9, pp. 840-851, 1972.

[21] L. N. Plummer and E. Busenberg, "The solubilities of calcite, aragonite and vaterite in $\mathrm{CO}_{2}-\mathrm{H}_{2} \mathrm{O}$ solutions between 0 and $90^{\circ} \mathrm{C}$, and an evaluation of the aqueous model for the system $\mathrm{CaCO}_{3}-\mathrm{CO}_{2}-\mathrm{H}_{2} \mathrm{O}$," Geochimica et Cosmochimica Acta, vol. 46, no. 6, pp. 1011-1040, 1982.

[22] O. S. Pokrovsky, S. V. Golubev, and J. Schott, "Dissolution kinetics of calcite, dolomite and magnesite at $25^{\circ} \mathrm{C}$ and 0 to 50 atm $\mathrm{pCO}_{2}$," Chemical Geology, vol. 217, no. 3-4, pp. 239255, 2005.

[23] O. S. Pokrovsky, S. V. Golubev, J. Schott, and A. Castillo, "Calcite, dolomite and magnesite dissolution kinetics in aqueous solutions at acid to circumneutral $\mathrm{pH}, 25$ to $150^{\circ} \mathrm{C}$ and 1 to 55 atm $p \mathrm{CO}_{2}$ : new constraints on $\mathrm{CO}_{2}$ sequestration in sedimentary basins," Chemical Geology, vol. 265, no. 1-2, pp. 20-32, 2009.

[24] Y. J. Zhao, F. G. Wang, C. S. Li, F. S. Wu, and Y. Q. Cao, "Carbonate karst erosion experiment research of Guizhou Huangguoshu tunnel," Coal Technology, vol. 35, no. 7, pp. 310-312, 2016.

[25] H. Cai, Z. Chen, and H. Zhou, "Impact analysis of fracture on the karst development and groundwater flow of Wulong cave," Safety \& Environmental Engineering, vol. 22, no. 2, pp. 1-6, 2015.

[26] G. Kaufmann, "Modelling karst aquifer evolution in fractured, porous rocks," Journal of Hydrology, vol. 543, Part B, pp. 796$807,2016$.

[27] J. Siemers and W. Dreybrodt, "Early development of karst aquifers on percolation networks of fractures in limestone," Water Resources Research, vol. 34, no. 3, pp. 409-419, 1998.

[28] W. Dreybrodt, "Principles of early development of karst conduits under natural and man-made conditions revealed by mathematical analysis of numerical models," Water Resources Research, vol. 32, no. 9, pp. 2923-2935, 1996. 
[29] W. Dreybrodt, Processes in Karst Systems: Physics, Chemistry, and Geology, Springer Series in Physical Environment, Springer, Berlin, Heidelberg, 1988.

[30] W. Dreybrodt, "The role of dissolution kinetics in the development of karst aquifers in limestone: a model simulation of karst evolution," Journal of Geology, vol. 98, no. 5, pp. 639655, 1990.

[31] W. Dreybrodt and F. Gabrovšek, "Dynamics of the evolution of a single karst conduit," in Speleogenesis: Evolution of Karst Aquifers, A. Klimchouk, D. C. Ford, A. N. Palmer, and W. Dreybrodt, Eds., pp. 184-193, National Speleological Society, Huntsville, AL, USA, 2000.

[32] R. B. Hanna and H. Rajaram, "Influence of aperture variability on dissolutional growth of fissures in karst formations," Water Resources Research, vol. 34, no. 11, pp. 2843-2853, 1998.

[33] A. N. Palmer, "Origin and morphology of limestone caves," Geological Society of America Bulletin, vol. 103, no. 1, pp. 1-21, 1991.

[34] W. K. Annable, Numerical analysis of conduit evolution in karstic aquifers, [Ph.D. thesis], University of Waterloo, Waterloo, ON, Canada, 2003.

[35] T. Hiller, G. Kaufmann, and D. Romanov, "Karstification beneath dam-sites: from conceptual models to realistic scenarios," Journal of Hydrology, vol. 398, no. 3-4, pp. 202-211, 2011.

[36] G. Kaufmann, "Modelling karst geomorphology on different time scales," Geomorphology, vol. 106, no. 1-2, pp. 62-77, 2009.

[37] G. Kaufmann, D. Romanov, and T. Hiller, "Modeling threedimensional karst aquifer evolution using different matrixflow contributions," Journal of Hydrology, vol. 388, no. 3-4, pp. 241-250, 2010.

[38] Q. Liu, Y. R. Lu, F. E. Zhang, J. X. Qi, and S. Zhang, "Qualitative analysis of microcorrosion of limestone induced by temperature and hydrodynamic pressure," Rock and Soil Mechanics, vol. 31, no. S2, pp. 149-154, 2010.

[39] H. D. Yu, D. Yang, D. Wang, and M. Y. Han, “Top-down fabrication of calcite nanoshoot arrays by crystal dissolution," Advanced Materials, vol. 22, no. 29, pp. 3181-3184, 2010.

[40] W. H. Zhu, X. Y. Qu, L. W. Qiu, Y. Chen, F. X. Gong, and S. X. $\mathrm{Wu}$, "Characteristics and erosion mechanism of carbonate in acetic acid and hydrochloride solutions, an example from the Nanpu depression," Bulletin of Mineralogy, Petrology and Geochemistry, vol. 34, pp. 619-625, 2015.

[41] U. Svensson and W. Dreybrodt, "Dissolution kinetics of natural calcite minerals in $\mathrm{CO}_{2}$-water systems approaching calcite equilibrium," Chemical Geology, vol. 100, no. 1-2, pp. 129145, 1992.

[42] P. Cubillas, S. Köhler, M. Prieto, C. Causserand, and E. H. Oelkers, "How do mineral coatings affect dissolution rates? An experimental study of coupled $\mathrm{CaCO}_{3}$ dissolution- $\mathrm{CdCO}_{3}$ precipitation," Geochimica et Cosmochimica Acta, vol. 69, no. 23, pp. 5459-5476, 2005.

[43] D. W. Finneran and J. W. Morse, "Calcite dissolution kinetics in saline waters," Chemical Geology, vol. 268, no. 1-2, pp. 137146, 2009.

[44] C. Fischer, I. Kurganskaya, T. Schäfer, and A. Lüttge, "Variability of crystal surface reactivity: what do we know?," Applied Geochemistry, vol. 43, pp. 132-157, 2014.
[45] E. Busenberg and L. Niel Plummer, "Kinetic and thermodynamic factors controlling the distribution of $\mathrm{SO}_{3}{ }^{2-}$ and $\mathrm{Na}^{+}$ in calcites and selected aragonites," Geochimica et Cosmochimica Acta, vol. 49, no. 3, pp. 713-725, 1985.

[46] D. K. Gledhill and J. W. Morse, "Calcite dissolution kinetics in $\mathrm{Na}-\mathrm{Ca}-\mathrm{Mg}-\mathrm{Cl}$ brines," Geochimica et Cosmochimica Acta, vol. 70, no. 23, pp. 5802-5813, 2006.

[47] Q. Gong, J. Deng, Q. Wang, L. Yang, and M. She, "Experimental determination of calcite dissolution rates and equilibrium concentrations in deionized water approaching calcite equilibrium," Journal of Earth Science, vol. 21, no. 4, pp. 402-411, 2010.

[48] A. C. Lasaga and A. Lüttge, "Mineralogical approaches to fundamental crystal dissolution kinetics," American Mineralogist, vol. 89, no. 4, pp. 527-540, 2004.

[49] A. Lüttge, "Crystal dissolution kinetics and Gibbs free energy," Journal of Electron Spectroscopy and Related Phenomena, vol. 150, no. 2-3, pp. 248-259, 2006.

[50] Q. Gong, J. Deng, Q. Wang, L. Yang, and M. She, "Calcite dissolution in deionized water from $50^{\circ} \mathrm{C}$ to $250^{\circ} \mathrm{C}$ at $10 \mathrm{MPa}$ : rate equation and reaction order," Acta Geologica Sinica - English Edition, vol. 82, no. 5, pp. 994-1001, 2008.

[51] R. Shiraki and S. L. Brantley, "Kinetics of near-equilibrium calcite precipitation at $100^{\circ} \mathrm{C}$ : an evaluation of elementary reaction-based and affinity-based rate laws," Geochimica et Cosmochimica Acta, vol. 59, no. 8, pp. 1457-1471, 1995.

[52] K. Adamczyk, M. Premont-Schwarz, D. Pines, E. Pines, and E. T. J. Nibbering, "Real-time observation of carbonic acid formation in aqueous solution," Science, vol. 326, no. 5960, pp. 1690-1694, 2009.

[53] J. Xu, C. Fan, and H. H. Teng, "Calcite dissolution kinetics in view of Gibbs free energy, dislocation density, and $\mathrm{pCO}_{2}$," Chemical Geology, vol. 322-323, pp. 11-18, 2012.

[54] W. Zhou and B. F. Beck, "Engineering issues on karst," in Karst Management, P. E. Beynen, Ed., pp. 9-45, Springer, Dordrecht, Netherlands, 2011.

[55] X. H. Zhang and Q. W. Liu, "Analysis of the features of water outbursts from underground rivers and the countermeasures in Wulong tunnel," Modern Tunnelling Technology, vol. 42, pp. 59-64, 2005.

[56] A. Amann Hildenbrand, J. P. Dietrichs, and B. M. Krooss, "Effective gas permeability of tight gas sandstones as a function of capillary pressure - a non-steady-state approach," Geofluids, vol. 16, no. 3, 383 pages, 2016.

[57] J. Angelier, F. Bergerat, O. Dauteuil, and T. Villemin, "Effective tension-shear relationships in extensional fissure swarms, axial rift zone of Northeastern Iceland," Journal of Structural Geology, vol. 19, no. 5, pp. 673-685, 1997.

[58] D. R. Faulkner, C. A. L. Jackson, R. J. Lunn et al., "A review of recent developments concerning the structure, mechanics and fluid flow properties of fault zones," Journal of Structural Geology, vol. 32, no. 11, pp. 1557-1575, 2010.

[59] A. Giwelli, C. Delle Piane, L. Esteban et al., "Laboratory observations of fault transmissibility alteration in carbonate rock during direct shearing," Geofluids, vol. 16, no. 4, 672 pages, 2016.

[60] M. Johri, E. M. Dunham, M. D. Zoback, and Z. Fang, "Predicting fault damage zones by modeling dynamic rupture propagation and comparison with field observations," Journal of Geophysical Research: Solid Earth, vol. 119, no. 2, pp. 12511272, 2014. 
[61] L. Micarelli, A. Benedicto, and C. A. J. Wibberley, "Structural evolution and permeability of normal fault zones in highly porous carbonate rocks," Journal of Structural Geology, vol. 28, no. 7, pp. 1214-1227, 2006.

[62] J. He, Y. Kang, D. Liu, M. Lei, and Z. Shu, "The stress sensitivity research on porous and fractured porous carbonate reservoirs," Drilling \& Production Technology, vol. 28, no. 2, pp. 84-86, 2005.

[63] D. Q. Li, Y. L. Kang, and L. J. You, "Experimental study on permeability stress sensitivity of carbonate rocks," Natural Gas Geoscience, vol. 202, no. 3, pp. 12-22, 2014.

[64] Y. Wan, J. Zan, and H. Tao, "Study on pore structure of carbonate reservoir," Oil-Gas Field Surface Engineering, vol. 27, no. 12, pp. 13-14, 2008.

[65] D. Zhu and Q. Li, "Predication of outflow in tunnel based on experimental permeating coefficient of precipitation," Journal of Railway Engineering Society, vol. 1, pp. 100-102, 1995.

[66] T. Xu, E. Sonnenthal, N. Spycher, and K. Pruess, "TOUGHREACT - a simulation program for non-isothermal multiphase reactive geochemical transport in variably saturated geologic media: applications to geothermal injectivity and $\mathrm{CO}_{2}$ geological sequestration," Computers \& Geosciences, vol. 32, no. 2, pp. 145-165, 2006.

[67] L. Yang, T. Xu, M. Wei, G. Feng, F. Wang, and K. Wang, "Dissolution of arkose in dilute acetic acid solution under conditions relevant to burial diagenesis," Applied Geochemistry, vol. 54, pp. 65-73, 2015.

[68] S. Y. Huang, "The corrosion of carbonates and environment temperature," Carsologica Sinica, vol. 4, pp. 287-296, 1987. 

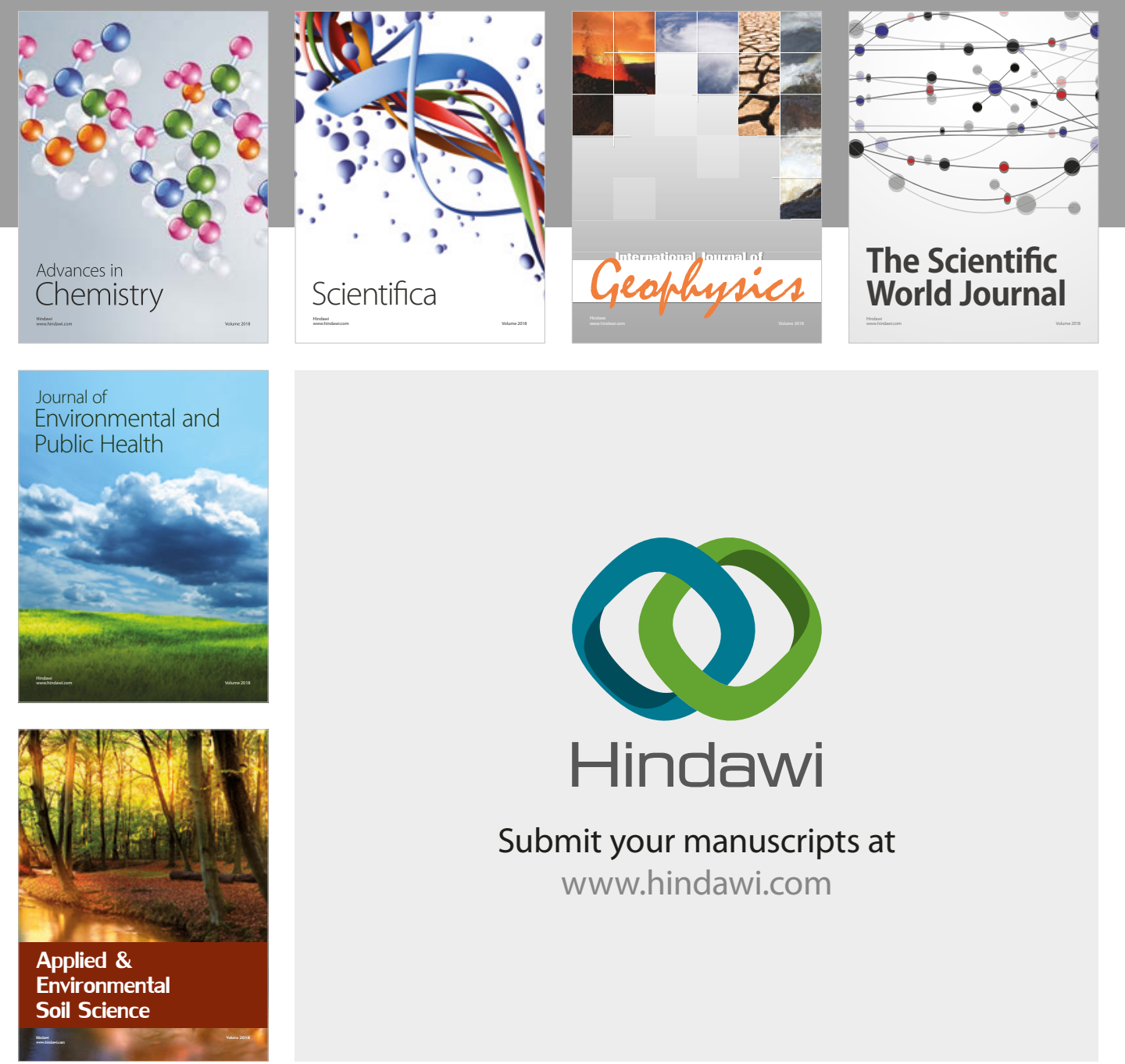

The Scientific

\section{World Journal}
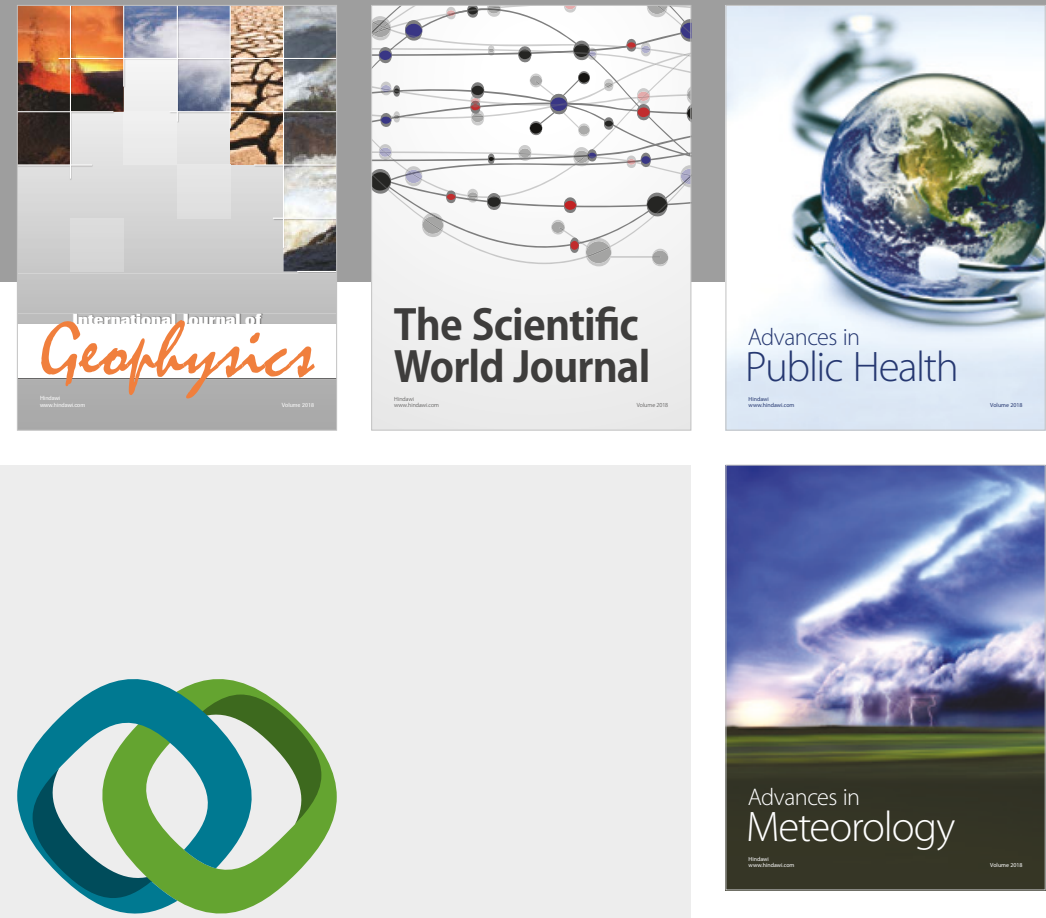

Advan

Public Health

\section{Hindawi}

Submit your manuscripts at

www.hindawi.com
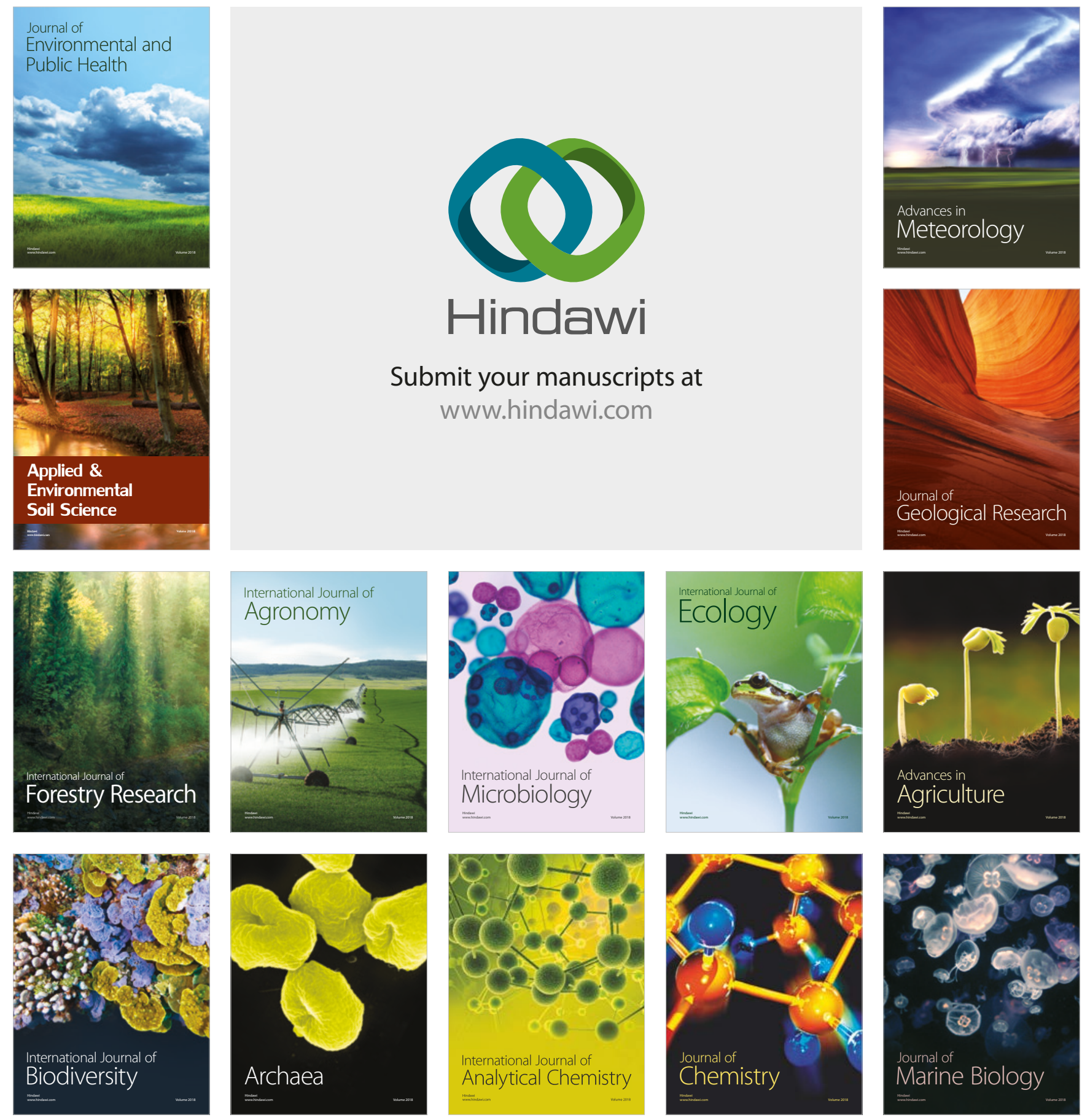